\title{
Potassium carbonate as a cation source for early-lactation dairy cows fed high-concentrate diets
}

\author{
A. R. Alfonso-Avila, ${ }^{*}$ É. Charbonneau, ${ }^{*}$ P. Y. Chouinard, ${ }^{*}$ G. F. Tremblay, $†$ and R. Gervais*1 \\ *Département des Sciences Animales, Université Laval, Québec, QC, Canada G1V 0A6 \\ †Québec Research and Development Centre, Agriculture and Agri-Food Canada, Québec, QC, Canada GIV 2J3
}

\begin{abstract}
Previous studies reported that addition of $\mathrm{K}_{2} \mathrm{CO}_{3}$ to high-concentrate diets improved milk fat synthesis, although the mechanism is yet to be established. The objective of the current experiment was to investigate the effects of dietary cation-anion difference (DCAD), cation source, and buffering ability of the mineral supplement on rumen biohydrogenation of fatty acids and production performance in dairy cows fed a highconcentrate diet. Thirty-five early-lactation Holstein cows (25 multiparous ruminally fistulated and 10 primiparous nonfistulated) were used in a randomized complete block design (7 blocks) with 33-d periods, including a 5-d pre-treatment collection period used as a covariate. Diets were (1) control, a basal diet $[47 \%$ nonfibrous carbohydrates, DCAD $(\mathrm{Na}+\mathrm{K}-\mathrm{Cl}-\mathrm{S})=$ $65 \mathrm{mEq} / \mathrm{kg}$ of dry matter (DM)] containing $40 \%$ forage (including $60 \%$ corn silage) and $60 \%$ concentrate, (2) $\mathrm{K}_{2} \mathrm{CO}_{3}$ (control $+\mathrm{K}_{2} \mathrm{CO}_{3}, 1.8 \%$ of $\mathrm{DM}, \mathrm{DCAD}=326$ $\mathrm{mEq} / \mathrm{kg}$ of DM), (3) $\mathrm{KHCO}_{3}$ (control $+\mathrm{KHCO}_{3}, 2.6 \%$ of DM, DCAD = $324 \mathrm{mEq} / \mathrm{kg}$ of DM), (4) $\mathrm{KCl}$ (control $+\mathrm{KCl}, 2.0 \%$ of DM, DCAD $=64 \mathrm{mEq} / \mathrm{kg}$ of $\mathrm{DM})$, and (5) $\mathrm{Na}_{2} \mathrm{CO}_{3}$ (control $+\mathrm{Na}_{2} \mathrm{CO}_{3}, 1.4 \%$ of DM, DCAD = $322 \mathrm{mEq} / \mathrm{kg}$ of DM). Pre-planned orthogonal contrasts were used to assess the effects of $\mathrm{K}_{2} \mathrm{CO}_{3}$ (control vs. $\mathrm{K}_{2} \mathrm{CO}_{3}$ ), buffering ability $\left(\mathrm{K}_{2} \mathrm{CO}_{3}\right.$ vs. $\left.\mathrm{KHCO}_{3}\right)$, DCAD $\left(\mathrm{K}_{2} \mathrm{CO}_{3}\right.$ vs. $\left.\mathrm{KCl}\right)$, and cation type $\left(\mathrm{K}_{2} \mathrm{CO}_{3}\right.$ vs. $\left.\mathrm{Na}_{2} \mathrm{CO}_{3}\right)$. Supplementing $\mathrm{K}_{2} \mathrm{CO}_{3}$ in a high-concentrate diet did not improve milk fat yield or $4 \%$ fat-corrected milk yield. Milk fat concentration was greater in cows fed $\mathrm{K}_{2} \mathrm{CO}_{3}$ compared with control (4.03 vs. $3.26 \%$ ). Milk yield tended to decrease (34.5 vs. $38.8 \mathrm{~kg} / \mathrm{d}$ ) and lactose yield decreased in cows fed $\mathrm{K}_{2} \mathrm{CO}_{3}$ as compared with $\mathrm{KCl}(1.64$ vs. $1.87 \mathrm{~kg} / \mathrm{d})$. Milk fat concentration of trans-10 18:1 was increased when cows were fed $\mathrm{Na}_{2} \mathrm{CO}_{3}$ as compared with $\mathrm{K}_{2} \mathrm{CO}_{3}$. A positive relationship was
\end{abstract}

Received July 25, 2016.

Accepted October 23, 2016.

${ }^{1}$ Corresponding author: rachel.gervais@fsaa.ulaval.ca observed between concentrations of anteiso 15:0 and trans-10, cis-12 18:2 in milk fat from cows receiving $\mathrm{K}_{2} \mathrm{CO}_{3}$. Milk Na concentration was increased, whereas milk $\mathrm{Cl}$ was decreased with $\mathrm{K}_{2} \mathrm{CO}_{3}$ as compared with $\mathrm{KHCO}_{3}$ or $\mathrm{KCl}$. A positive relationship was established between milk $\mathrm{Cl}$ concentration and milk yield $\left(\mathrm{R}^{2}=\right.$ $0.34)$ across all dietary treatments. Cation-anion difference $(\mathrm{Na}+\mathrm{K}-\mathrm{Cl}-\mathrm{S})$ in ruminal fluid was increased with $\mathrm{K}_{2} \mathrm{CO}_{3}$ as compared with control or $\mathrm{KCl}$. Blood $\mathrm{pH}$ tended to decrease in cows fed $\mathrm{KCl}$ compared with $\mathrm{K}_{2} \mathrm{CO}_{3}$. Our results suggest that mineral supplementation tends to affect milk and milk fat synthesis and that factors other than DCAD, potassium ion, or buffer ability may be implicated. The variations observed in mineral composition of milk suggest an allostatic process to maintain an ionic equilibrium in mammary epithelial cells in response to mineral composition of the diet.

Key words: dietary cation-anion difference, potassium carbonate, milk fat synthesis, chlorine

\section{INTRODUCTION}

Negative energy balance typically appears in earlylactation dairy cows as a consequence of a reduction of DMI, as well as an increase in energy demand for milk production (Grummer, 1993). To compensate for this energy deficit, cows are fed high-concentrate diets. However, highly fermentable carbohydrates introduced in diets can result in a decreased rumen $\mathrm{pH}$, and consequently lead to subacute ruminal acidosis (Nocek, 1997; Krause and Oetzel, 2006). Under these conditions, the pattern of fermentation is altered, increasing rumen appearance of biohydrogenation intermediates derived from dietary PUFA, such as trans-10,cis-12 CLA (Baumgard et al., 2000) and trans-9,cis-11 CLA (Perfield et al., 2007), which are recognized for their inhibitory effects on milk fat synthesis.

Davis and Brown (1970) characterized "low-fat milk syndrome" as a consequence of diets with a high ratio of readily digestible carbohydrates to fibrous constituents that can create unfavorable conditions within the 
rumen. Based on these observations, different types of minerals were proposed to help stabilize the rumen $\mathrm{pH}$ and thus reduce the incidence of milk fat depression (Emery and Brown, 1961). More recently, it has been demonstrated that increasing the DCAD through mineral supplementation of diets containing 20 or $40 \%$ (DM basis) of concentrates increased the synthesis of milk and milk fat (Apper-Bossard et al., 2010). The authors suggested that responses were related to the capacity to maintain blood $\mathrm{pH}$ via an increase in blood $\mathrm{HCO}_{3}^{-}$, as well as a localized rumen buffering effect. In vitro studies have shown that the addition of $\mathrm{K}_{2} \mathrm{CO}_{3}$ promotes the predominant pathway of fatty acid (FA) biohydrogenation, which is characterized by the formation of trans-11 18:1 and cis-9,trans-11 CLA as intermediates (Jenkins et al., 2014). Moreover, $\mathrm{K}_{2} \mathrm{CO}_{3}$ supplementation reduced outflows of isomers used as markers for altered rumen biohydrogenation pathways (trans-10 18:1), or linked directly with milk fat depression (e.g., trans-10,cis-12 CLA; Jenkins et al., 2014). Likewise, it has been reported that $\mathrm{K}_{2} \mathrm{CO}_{3}$ may counteract the negative effects of high-concentrate diets on milk fat synthesis (West et al., 1986; Harrison et al., 2012). Our hypothesis is that the effects observed on milk fat synthesis when $\mathrm{K}_{2} \mathrm{CO}_{3}$ is fed to dairy cows could originate from changes in the rumen environment and the acid-base status of the animal, given that supplementation of dairy cow diets with $\mathrm{K}_{2} \mathrm{CO}_{3}$ increases $\mathrm{K}$ ion concentration, DCAD, and buffer ability. However, the mechanism by which $\mathrm{K}_{2} \mathrm{CO}_{3}$ supplementation might decrease the effect of high-concentrate diets on milk fat depression is yet to be established.

The objective of the current study was to investigate the effects of $\mathrm{K}_{2} \mathrm{CO}_{3}$, buffering ability of the mineral supplement, DCAD, and cation source on milk production and composition in early-lactation dairy cows fed a high-concentrate diet.

\section{MATERIALS AND METHODS}

\section{Cows, Experimental Design, and Treatments}

The experiment was carried out at the Centre de Recherche en Sciences Animales de Deschambault (Deschambault, Quebec, Canada) and all the procedures with cows were approved by the animal care committee of Université Laval in accordance with the guidelines of the Canadian Council on Animal Care (1993).

Thirty-five lactating Holstein cows (25 multiparous ruminally fistulated and 10 primiparous nonfistulated) averaging $37 \pm 13$ DIM (mean $\pm \mathrm{SD}$ ), $618 \pm 59 \mathrm{~kg}$ of BW, and producing $39.6 \pm 8.0 \mathrm{~kg} / \mathrm{d}$ of milk were used in a randomized complete block design. Cows were blocked by expecting calving date, parity (primipa- rous and multiparous), and cannulation. Blocks were completed successively from January to July 2013 and consisted of groups of 5 cows calving over an interval of $25 \pm 18$ d. Within each block, cows were randomly assigned to the experimental diets. The experiment started with a 5-d pretreatment collection period, used as a covariate. During this time, cows were fed a diet with a forage-to-concentrate ratio of 53:47 (Table 1). The treatment period lasted $28 \mathrm{~d}$, of which $23 \mathrm{~d}$ were for adaptation and the last $5 \mathrm{~d}$ were used for data and sample collections. All cows were housed in individual tie stalls and had free access to water at all time.

Treatment diets consisted of (1) a control basal diet formulated to contain, on a DM basis, $40 \%$ forage (including $60 \%$ corn silage) and $60 \%$ concentrate (total diet containing $47 \% \mathrm{NFC}$ and $24 \%$ amylase-treated $\mathrm{NDF}$, with a DCAD of $65 \mathrm{mEq} / \mathrm{kg}$ of DM; control); (2) the control diet $+1.8 \% \mathrm{~K}_{2} \mathrm{CO}_{3}$ with a DCAD of $326 \mathrm{mEq} / \mathrm{kg}$ of $\mathrm{DM}\left(\mathbf{K}_{2} \mathbf{C O}_{3}\right)$; (3) control diet + $2.6 \% \mathrm{KHCO}_{3}$ with a DCAD of $324 \mathrm{mEq} / \mathrm{kg}$ of DM $\left(\mathbf{K H C O}_{3}\right)$; (4) the control diet $+2.0 \% \mathrm{KCl}$ with a DCAD of $64 \mathrm{mEq} / \mathrm{kg}$ of DM $(\mathbf{K C l})$; and (5) the control diet $+1.4 \% \mathrm{Na}_{2} \mathrm{CO}_{3}$ with a DCAD of $322 \mathrm{mEq} / \mathrm{kg}$ of DM $\left(\mathrm{Na}_{2} \mathbf{C O}_{3}\right)$. Based on initial feed ingredient composition, diets were formulated to meet or exceed the NRC (2001) requirements (Table 1). Diets were fed as TMR at $1000 \mathrm{~h}$ daily and the amounts of feed offered were adjusted at $110 \%$ of expected intake according to the previous day consumption. The forages were sampled every week and dried for $3 \mathrm{~d}$ in a forced-air oven at $55^{\circ} \mathrm{C}$ to determine $\mathrm{DM}$ concentration and adjust the as-fed forage proportions in the diets.

\section{Experimental Measurements and Sampling}

In each collection period, BW was registered at 0930 $\mathrm{h}$ for the last $3 \mathrm{~d}$. Samples of TMR and orts were collected for the last 5 consecutive days during the pretreatment and the experimental periods and stored at $-20^{\circ} \mathrm{C}$. Prior to analysis, samples of TMR and orts were thawed at room temperature and dried in a forced-air oven for $72 \mathrm{~h}$ at $55^{\circ} \mathrm{C}$ to determine DM concentration. Dried samples were ground to $2 \mathrm{~mm}$ using a Wiley mill (model 4, Arthur M. Thomas Co., Philadelphia, PA), pooled by cow and period, ground again to $1 \mathrm{~mm}$ using a Cyclotec Sample Mill (model 1093, Tecator Inc., Höganäs, Sweden), and kept frozen at $-20^{\circ} \mathrm{C}$ until further analyses.

All TMR and orts were analyzed as described by Fauteux et al. (2016), including ash (method 942.05; AOAC International, 2000) and starch (Hall, 2009).

Additionally, subsamples of TMR and orts were subjected to a digestion process in $\mathrm{HNO}_{3}(70 \%)+\mathrm{H}_{2} \mathrm{O}_{2}$ $(30 \%)$, according to a procedure adapted from Mills 
Table 1. Ingredients and chemical composition of the experimental TMR

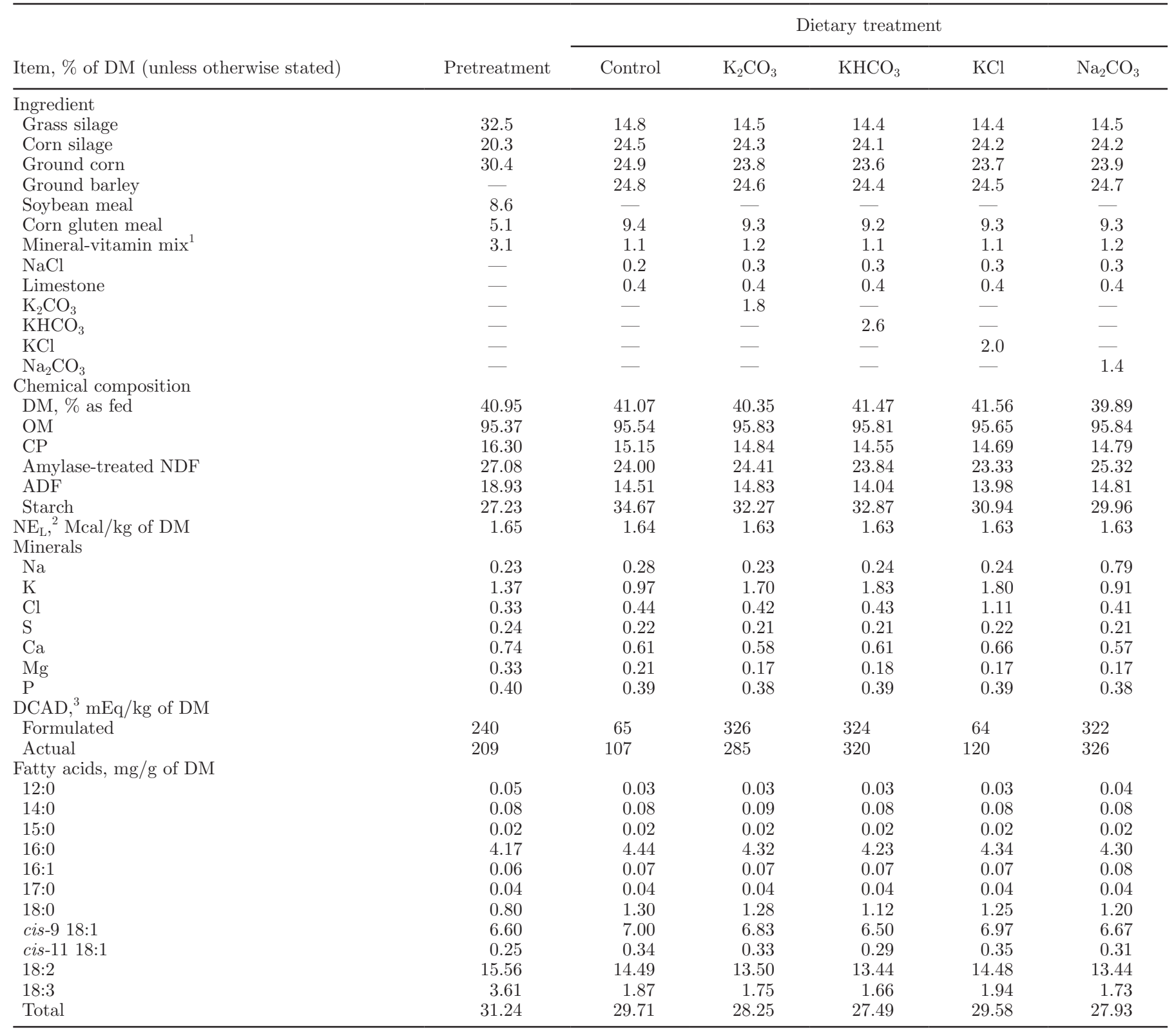

${ }^{1}$ Optima 20-4, La Coop, St-Romuald, QC, Canada.

${ }^{2}$ Calculated according to NRC (2001).

${ }^{3} \mathrm{DCAD}=[\mathrm{Na}+\mathrm{K}]-[\mathrm{Cl}+\mathrm{S}]$.

and Jones (1996) using a digestion block (DigiPREP MS, SCP Science, Baie d'Urfé, QC, Canada) for CP and mineral (except $\mathrm{Cl}$ ) determinations. Subsequently, $\mathrm{CP}(\mathrm{N} \times 6.25)$ was assessed using an autoanalyzer (QuikChem 8000 Lachat Zellweger Analytics Inc., Lachat Instruments, Milwaukee, WI; method 13-107-06-2-D; Lachat Instruments, 2013). Concentrations of P, K, Ca, $\mathrm{Mg}, \mathrm{Na}$, and $\mathrm{S}$ were determined by inductively coupled plasma optical emission spectrometry (ICP-OES, Opti- ma 4300DV, Perkin Elmer, Shelton, CT). Finally, Cl in TMR and orts was extracted using a method adapted from Liu (1998). Briefly, $0.25 \mathrm{~g}$ of dried and ground samples were mixed with $20 \mathrm{~mL}$ of $\mathrm{H}_{2} \mathrm{SO}_{4}(0.007 M)$ for $60 \mathrm{~min}$ and then centrifuged at $32,570 \times \mathrm{g}$ for $30 \mathrm{~min}$ at room temperature. The concentration of $\mathrm{Cl}$ in the last supernatant was determined using an ion chromatograph (model ICS-2100, Dionex Corp., Sunnyvale, CA) equipped with an AS11 HC capillary column (Dionex 
Corp.). Determination of dietary FA composition was carried out by gas chromatography according to the method described by Fauteux et al. (2016).

Cows were milked twice daily at 0700 and $1700 \mathrm{~h}$, and milk yield was determined using calibrated milk meters (Flowmaster Pro, DeLaval, Tumba, Sweden) for the last $3 \mathrm{~d}$ in each collection period. Milk samples were composited daily from evening and morning milking proportionately to respective milk yields. A first composited subsample was stored at $4^{\circ} \mathrm{C}$ with bronopol (2-bromo-2-nitropropane-1,3-diol) until further determination of milk fat, protein, lactose, and MUN by the method 972.160 (AOAC International, 2012) at Valacta (Ste-Anne-de-Bellevue, QC, Canada), using a Foss MilkoScan FT 6000 (Foss, Hillerød, Denmark). Somatic cell count was also determined at Valacta using a Fossomatic FC (Foss). A second composite milk subsample was pooled by cow and period without preservative for subsequent determination of mineral and FA composition.

Lipid extraction of milk samples and methylation of FA were performed according to procedures described by Chouinard et al. (1997). Milk FA profile was determined according to Boivin et al. (2013), using a gas chromatograph (Agilent 7890A, Agilent Technologies, Santa Clara, CA) equipped with a 100-m CP-Sil-88 capillary column $(0.25 \mathrm{~mm}$ i.d., $0.20 \mathrm{~mm}$ film thickness; Agilent Technologies Canada Inc., Mississauga, ON, Canada) and a flame ionization detector.

Milk concentrations of $\mathrm{P}, \mathrm{K}, \mathrm{Ca}, \mathrm{Mg}, \mathrm{Na}$, and $\mathrm{S}$ were determined according to methods described above for feed and ort samples. For $\mathrm{Cl}$ concentration, a 1-mL sample was ashed in a muffle furnace at $550^{\circ} \mathrm{C}$ for 5 $\mathrm{h}$ and then solubilized in $1 \mathrm{~mL}$ of $0.5 \mathrm{NHNO}_{3}$ and diluted with distilled water to a final volume of $50 \mathrm{~mL}$. Milk concentration of $\mathrm{Cl}$ was determined as described by Gaucheron et al. (1996), using an ion chromatograph (model ICS-2100, Dionex Corp., Sunnyvale, CA) equipped with an AS11 HC capillary column (Dionex Corp.).

Rumen fluid was collected from the ventral sac of rumen fistulated cows on 2 consecutive days of each collection period at $0,1,2,4,6$, and $8 \mathrm{~h}$ relative to feeding time. Rumen fluid was collected and filtered using a sampler tube (Bar-Diamond Inc., Parma, ID). Following an immediate $\mathrm{pH}$ measurement (pHTestr 30, Oakton Instruments, Vernon Hills, IL), $10 \mathrm{~mL}$ of rumen fluid was stabilized with $0.2 \mathrm{~mL}$ of $\mathrm{H}_{2} \mathrm{SO}_{4}(50 \%$, vol/ vol) and stored at $-20^{\circ} \mathrm{C}$ until determination of VFA and $\mathrm{NH}_{3}-\mathrm{N}$ concentrations. A second sample $(15 \mathrm{~mL})$ of rumen fluid was collected and stored at $-20^{\circ} \mathrm{C}$ before analyses of mineral composition. Ruminal cation-anion difference (RCAD) was calculated as follows:

$$
\operatorname{RCAD}(\mathrm{mEq} / \mathrm{L})=[\mathrm{Na}+\mathrm{K}]-[\mathrm{Cl}+\mathrm{S}] .
$$

At the time of analysis, acidified samples of rumen fluid were thawed and centrifuged at $16,060 \times g$ for $15 \mathrm{~min}$ at $4^{\circ} \mathrm{C}$. The supernatant was analyzed for $\mathrm{NH}_{3}-\mathrm{N}$ with the indophenol-blue method (Novozamsky et al., 1974) using a spectrophotometer (Spectronic 1201, Milton Roy Company, Miami, FL) at $630 \mathrm{~nm}$. The profile of ruminal VFA was determined with a gas chromatograph (Clarus 680, Perkin Elmer, Waltham, MA) equipped with a polar capillary column (HP-Innowax 30-m length, $0.320 \mathrm{~mm}$ i.d., $0.25 \mu \mathrm{m}$ film thickness; Agilent Technologies Canada Inc.) and a flame ionization detector. The split ratio was 25:1. At the time of the sample injection, the column temperature was $80^{\circ} \mathrm{C}$, maintained for $0.5 \mathrm{~min}$ followed by a first increase to $180^{\circ} \mathrm{C}$ at $10^{\circ} \mathrm{C} / \mathrm{min}$, and a second increase to $220^{\circ} \mathrm{C}$ at $30^{\circ} \mathrm{C} / \mathrm{min}$. The temperature was then maintained at $220^{\circ} \mathrm{C}$ for $2 \mathrm{~min}$. The second sample of rumen fluid was thawed and centrifuged at $13,000 \times g$ for $30 \mathrm{~min}$ at $4^{\circ} \mathrm{C}$, the supernatants were then composited by day and cow, and concentrations of $\mathrm{P}, \mathrm{K}, \mathrm{Ca}, \mathrm{Mg}, \mathrm{Na}$, and $\mathrm{S}$ were determined according to the same procedure used for milk and dietary samples. Prior to the determination of $\mathrm{Cl}$ concentration in rumen fluid, samples were centrifuged a second time at $32,570 \times g$ for $30 \mathrm{~min}$ at $4^{\circ} \mathrm{C}$ and diluted in water with a $1: 3$ rumen fluid-towater ratio (Adriano and Doner, 1982; Johnson and Fixen, 1990). Determination of $\mathrm{Cl}$ was performed using ion chromatography, as described above.

On the last $2 \mathrm{~d}$ of each collection period, blood samples were taken at $0930 \mathrm{~h}$ (preprandial) and $1400 \mathrm{~h}$ (postprandial) from a jugular vein into evacuated tubes without preservative (Vacutainer 366430, Becton Dickinson, Franklin Lakes, NJ) and immediately transferred to $1.7-\mathrm{mL}$ syringes (Radiometer, Copenhagen, Denmark) containing $80 \mathrm{IU}$ of electrolyte-balanced heparin. Blood hematocrits, concentrations of electrolytes $\left(\mathrm{Na}^{+}\right.$, $\mathrm{K}^{+}, \mathrm{Ca}^{2+}$, and $\mathrm{Cl}^{-}$) and $\mathrm{HCO}_{3}{ }^{-}$, and partial pressure of $\mathrm{CO}_{2}$ and $\mathrm{O}_{2}$ were immediately determined by potentiometry using a blood gas and mineral analyzer (ABL 77, Radiometer).

\section{Statistical Analysis}

Data for milk production and composition, DMI, BW, and minerals in milk and rumen fluid were analyzed as a randomized block design using the GLIMMIX procedure of SAS (version 9.3; SAS Institute Inc., Cary, NC). The model used was

$$
\mathrm{Y}_{\mathrm{ij}}=\mu+\mathrm{T}_{\mathrm{i}}+\mathrm{B}_{\mathrm{j}}+\mathrm{C}+\varepsilon_{\mathrm{ij}},
$$


where $Y_{i j}$ is the variable observed, $\mu$ is the overall mean, $\mathrm{T}_{\mathrm{i}}$ denotes the fixed effect of treatment $(\mathrm{i}=1$ to 5$), \mathrm{B}_{\mathrm{j}}$ is the random effect of block ( $\mathrm{j}=1$ to 7 ), $\mathrm{C}$ is the covariable adjustment for each cow $(\mathrm{C}=1$ to 35$)$, and $\varepsilon_{\mathrm{ij}}$ denotes the residual error. Blood and rumen fermentation parameters were analyzed using the REPEATED statement in the MIXED procedure of SAS, using the following model:

$$
\begin{aligned}
\mathrm{Y}_{\mathrm{ijkl}}=\mu+ & \mathrm{T}_{\mathrm{i}}+\mathrm{H}_{\mathrm{j}}+(\mathrm{T} \times \mathrm{H})_{\mathrm{ij}}+\mathrm{A}\left(\mathrm{k}_{\mathrm{k}}\right)_{1} \\
& +\mathrm{B}_{\mathrm{l}}+\mathrm{C}+\varepsilon_{\mathrm{ijkl}},
\end{aligned}
$$

where $Y_{i j k l}$ is the variable observed, $\mu$ is the overall mean, $T_{i}$ denotes the fixed effect of treatment $(i=1$ to $5), \mathrm{H}_{\mathrm{j}}$ refers to fixed effect of sampling time $(\mathrm{j}=0$, and $4 \mathrm{~h}$ postprandial for blood parameters and $\mathrm{j}=0,1,2$, 4,6 , and $8 \mathrm{~h}$ postprandial for rumen parameters), ( $\mathrm{T}$ $\times \mathrm{H})_{\mathrm{ij}}$ is the fixed effect of the interaction, $\mathrm{A}\left(\mathrm{k}_{\mathrm{k}}\right)_{1}$ is the random effect of cow $\mathrm{k}(\mathrm{k}=1$ to 5$)$ within block $(\mathrm{l}=1$ to 7 ), $B_{1}$ is the random effect of block, $\mathrm{C}$ is the covariate adjustment for blood and rumen parameters of each cow $(\mathrm{C}=1$ to 35$)$, and $\varepsilon_{\mathrm{ijkl}}$ denotes the residual error. Cow within block was included in the model as the subject of the repeated statement. For blood parameters, covariance structures were selected between compound symmetry and first-order autoregressive based on the Akaike's information criterion. For rumen parameters, the spatial covariance structure was used to estimate covariances. Because no treatment $\times$ sampling time interaction was observed for blood parameters, as well as for rumen $\mathrm{pH}$ and VFA, values were combined by day and analyzed according to the model previously mentioned. Pre-planned orthogonal contrasts were used to assess the effects of $\mathrm{K}_{2} \mathrm{CO}_{3}$ (control vs. $\mathrm{K}_{2} \mathrm{CO}_{3}$ ), buffer ability $\left(\mathrm{K}_{2} \mathrm{CO}_{3}\right.$ vs. $\left.\mathrm{KHCO}_{3}\right)$, DCAD $\left(\mathrm{K}_{2} \mathrm{CO}_{3}\right.$ vs. $\left.\mathrm{KCl}\right)$, and cation source $\left(\mathrm{K}_{2} \mathrm{CO}_{3}\right.$ vs. $\left.\mathrm{Na}_{2} \mathrm{CO}_{3}\right)$. Simple linear regressions were conducted using the REG procedure of SAS to determine relationships between milk yield and milk minerals, and the association between milk fat concentration of trans-10, cis-12 18:2, and anteiso 15:0. Differences were declared significant at $P \leq 0.05$ and tendencies at $0.05<P \leq 0.10$.

\section{RESULTS AND DISCUSSION}

\section{Diets, DMI, and BW}

The actual DCAD were 107, 285, 320, 120, and 326 $\mathrm{mEq} / \mathrm{kg}$ of DM for control, $\mathrm{K}_{2} \mathrm{CO}_{3}, \mathrm{KHCO}_{3}, \mathrm{KCl}$, and $\mathrm{NaCO}_{3}$ experimental TMR, respectively (Table 1). Therefore, mineral supplementation allowed a modulation of DCAD, as formulated among treatments. Also, isokalemic conditions were maintained between $\mathrm{K}_{2} \mathrm{CO}_{3}$, $\mathrm{KHCO}_{3}$, and $\mathrm{KCl}$ treatments, as shown by the minimal variations observed in dietary $\mathrm{K}$ concentrations of these 3 treatments.

Supplementing cows with $\mathrm{K}_{2} \mathrm{CO}_{3}$ tended to decrease BW compared with the control diet (Table 2). However, no significant effect of mineral supplementation was observed on DMI (Table 2). Conversely, using a mineral mixture to increase DCAD from 0 to 300 $\mathrm{mEq} / \mathrm{kg}$ of DM of TMR, Apper-Bossard et al. (2010) observed a linear increase in DMI up to 1.9 and 4.0 $\mathrm{kg} / \mathrm{d}$ when cows received 20 and $40 \%$ of concentrate, respectively. Similarly, increasing DCAD (196 to 544 $\mathrm{mEq} / \mathrm{kg}$ of $\mathrm{DM}$ ) by increasing levels of $\mathrm{K}_{2} \mathrm{CO}_{3}$ in diets of dairy cows in established lactation (95 DIM) led to a concomitant increase in DMI up to $1.3 \mathrm{~kg} / \mathrm{d}$ (Iwaniuk et al., 2015). A systematic review conducted by $\mathrm{Hu}$ et al. (2007a) also reported a positive relationship between DMI and the acid-base status of lactating dairy cows. On the other hand, the same group of researchers reported no effect of 2 DCAD levels (220 vs. $470 \mathrm{mEq} /$ $\mathrm{kg}$ of DM) on DMI of cows in early lactation (1 to 47 DIM; Hu et al., 2007b). These authors attributed the discrepancies between studies due to tremendous physiological changes occurring in early lactation, which attenuated the effect of dietary treatments. Another possible implication of DCAD on DMI could be related to ion availability, because their manipulation always affects the regulation of cell volume, and consequently the transport of substrates into and out of the cell as well as regulation of osmotic pressure (McDowell, 1992; Hoffmann et al., 2009). Potassium contributes to $50 \%$ of the osmolality of intracellular fluid, whereas $\mathrm{Na}$ and $\mathrm{Cl}$ contribute to $80 \%$ of extracellular osmolality (McDowell, 1992). Although the cell has the capacity to adjust its requirements through ionic homeostasis, long-term exposure to anisosmotic conditions exerts changes that affect signaling events which control cell growth, proliferation, and death (Hoffmann et al., 2009). In this regard, it is important to notice that transport of nutrients across the rumen epithelium may be impaired. Studies support the existence of a shortchain FA transport mechanism in the epithelial cells that involves ions (Gäbel et al., 1991; Sehested et al., 2000), and this transport mechanism can be the cause of a feed-induced regulation (Sehested et al., 2000). In the current experiment, despite a variation in systemic acid-base status reflected by a tendency for lower blood $\mathrm{pH}$ (Table 3), cows fed $\mathrm{KCl}$ had a numerically higher DMI $(1.9 \mathrm{~kg} / \mathrm{d})$ compared with cows fed $\mathrm{K}_{2} \mathrm{CO}_{3}$ diet. Given that increasing DCAD do not necessary implicate keeping the ideal cell ionic balance of $\mathrm{K}, \mathrm{Na}$, and $\mathrm{Cl}$, we speculate that $\mathrm{KCl}$ as compared with $\mathrm{K}_{2} \mathrm{CO}_{3}$ 
Table 2. Dry matter intake, BW, and milk yield and composition of early-lactation cows receiving high-concentrate diets supplemented with different minerals

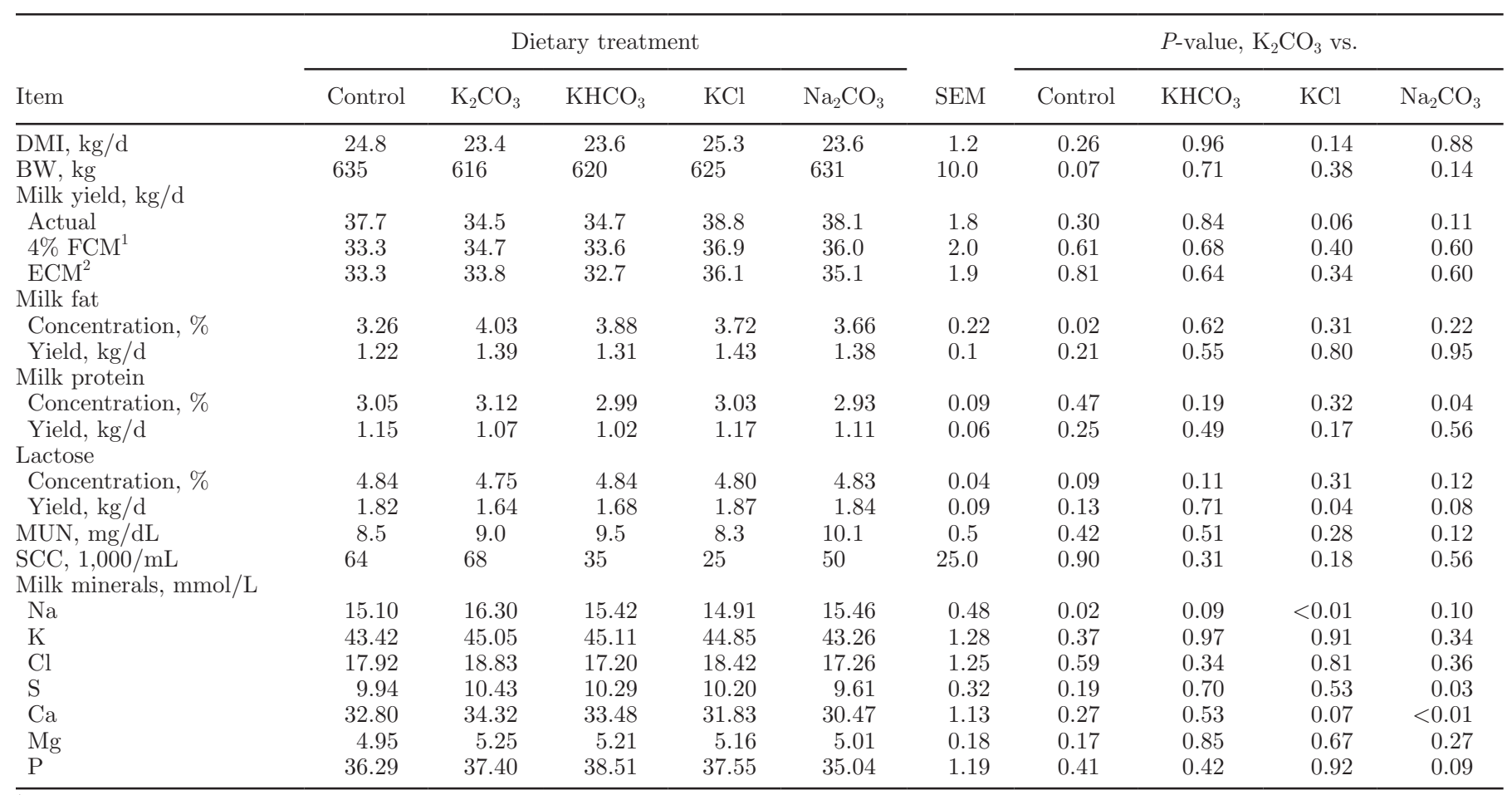

${ }^{1} 4 \% \mathrm{FCM}=[0.4 \times$ milk yield $(\mathrm{kg} / \mathrm{d})]+[15 \times$ fat yield $(\mathrm{kg} / \mathrm{d})]$.

${ }^{2} \mathrm{ECM}=0.327 \times$ milk yield $(\mathrm{kg} / \mathrm{d})+12.95 \times$ fat yield $(\mathrm{kg} / \mathrm{d})+7.2 \times$ protein yield $(\mathrm{kg} / \mathrm{d})$.

may provide possibly a better balance of ions in the rumen, allowing fewer feed-induced regulation effects.

Iwaniuk et al. (2015) evaluated the effect of cation sources $\left[\mathrm{Na}_{3} \mathrm{H}\left(\mathrm{CO}_{3}\right)_{2}\right.$ vs. $\left.\mathrm{K}_{2} \mathrm{CO}_{3}\right]$ on performance of dairy cows fed TMR with similar DCAD (approximately $380 \mathrm{mEq} / \mathrm{kg}$ of DM) and observed no difference on DMI. These results are in agreement with our findings where cation sources modulated through the supply of $\mathrm{Na}_{2} \mathrm{CO}_{3}$ or $\mathrm{K}_{2} \mathrm{CO}_{3}$ did not affect DMI.

Investigating dietary buffers effects on high-producing dairy cows, Erdman (1988) compiled literature data and showed that, as opposed to $\mathrm{KHCO}_{3}$, which did not affect DMI, adding $\mathrm{K}_{2} \mathrm{CO}_{3}$ did increase DMI compared with diets without $\mathrm{K}$ supplementation. The

Table 3. Blood parameters of early-lactation cows receiving high-concentrate diets supplemented with different minerals

\begin{tabular}{|c|c|c|c|c|c|c|c|c|c|c|}
\hline Parameter $^{1}$ & \multicolumn{5}{|c|}{ Dietary treatment } & SEM & \multicolumn{4}{|c|}{$P$-value, $\mathrm{K}_{2} \mathrm{CO}_{3}$ vs. } \\
\hline $\mathrm{pH}$ & 7.43 & 7.42 & 7.42 & 7.40 & 7.43 & 0.01 & 0.74 & 0.92 & 0.10 & 0.84 \\
\hline \multicolumn{11}{|l|}{ Electrolytes, mmol/L } \\
\hline $\mathrm{Na}^{+}$ & 139.7 & 140.1 & 140.0 & 140.4 & 139.6 & 0.4 & 0.46 & 0.85 & 0.58 & 0.36 \\
\hline $\mathrm{K}^{+}$ & 3.69 & 4.01 & 3.79 & 3.92 & 3.68 & 0.07 & $<0.01$ & 0.01 & 0.27 & $<0.01$ \\
\hline $\mathrm{Cl}^{-}$ & 105.9 & 106.1 & 106.5 & 108.0 & 105.3 & 0.8 & 0.84 & 0.61 & 0.04 & 0.41 \\
\hline $\mathrm{HCO}_{3}^{-}, \mathrm{mmol} / \mathrm{L}$ & 27.1 & 27.6 & 26.8 & 26.1 & 28.0 & 0.8 & 0.67 & 0.48 & 0.22 & 0.73 \\
\hline Hematocrit, $\%$ & 27.5 & 27.4 & 27.6 & 26.6 & 27.3 & 0.7 & 0.92 & 0.84 & 0.39 & 0.90 \\
\hline \multicolumn{11}{|l|}{ Blood gas, $\mathrm{mm} \mathrm{Hg}$} \\
\hline $\mathrm{pCO}_{2}$ & 41.9 & 43.1 & 41.5 & 42.5 & 43.4 & 0.9 & 0.38 & 0.24 & 0.66 & 0.82 \\
\hline $\mathrm{pO}_{2}$ & 36.9 & 37.9 & 38.9 & 36.9 & 38.6 & 1.8 & 0.60 & 0.53 & 0.56 & 0.66 \\
\hline
\end{tabular}

${ }^{1}$ Anion gap $=\left[\mathrm{K}^{+}+\mathrm{Na}^{+}\right]-\left[\mathrm{Cl}^{-}+\mathrm{HCO}_{3}{ }^{-}\right] ; \mathrm{HCO}_{3}{ }^{-}=$bicarbonate; $\mathrm{pCO}_{2}=$ partial pressure of $\mathrm{CO}_{2} ; \mathrm{pO}_{2}=$ partial pressure of $\mathrm{O}_{2}$. 
author suggested that the observed effects of mineral supplementation on DMI could be partly explained by a higher rumen $\mathrm{pH}$, associated with a more favorable rumen environment, allowing greater DM digestibility. West et al. (1986) also observed a greater DMI for cows supplemented with $\mathrm{K}_{2} \mathrm{CO}_{3}$ compared with $\mathrm{KHCO}_{3}$ or $\mathrm{NaHCO}_{3}$. In contrast, in the current trial, DMI was similar for cows fed $\mathrm{K}_{2} \mathrm{CO}_{3}$ and $\mathrm{KHCO}_{3}$ diets (23.5 $\pm 1.1 \mathrm{~kg} / \mathrm{d}$ ). This level of intake allowed a daily consumption of $3.05 \mathrm{~mol}$ of $\mathrm{CO}_{3}{ }^{2-}$ ions and $6.11 \mathrm{~mol}$ of $\mathrm{HCO}_{3}{ }^{-}$ions for $\mathrm{K}_{2} \mathrm{CO}_{3}$ and $\mathrm{KHCO}_{3}$ treatments, respectively. West et al. (1986) reported that, in the rumen, $\mathrm{CO}_{3}{ }^{2-}$ ions contained in $\mathrm{K}_{2} \mathrm{CO}_{3}$ has twice the capacity to absorb hydrogen ions compared with $\mathrm{HCO}_{3}{ }^{-}$ions found in $\mathrm{KHCO}_{3}$. Therefore, the isokalemic conditions maintained between $\mathrm{K}_{2} \mathrm{CO}_{3}$ and $\mathrm{KHCO}_{3}$ treatments led to an equivalent buffer ability of these 2 diets and could explain the lack of difference in DMI between these 2 treatments.

A trend to decreased BW was observed in cows fed $\mathrm{K}_{2} \mathrm{CO}_{3}$ as compared with control. This tendency could possibly be explained in part by a numerically lower DMI $(-1.4 \mathrm{~kg} / \mathrm{d})$ for $\mathrm{K}_{2} \mathrm{CO}_{3}$ as compared with the control treatment.

\section{Rumen Fermentation Attributes and Minerals}

As expected, concentration of $\mathrm{K}$ in the rumen was similar for cows fed $\mathrm{K}_{2} \mathrm{CO}_{3}$ and $\mathrm{KHCO}_{3}$ or $\mathrm{KCl}$ (Table 4). However, despite that $\mathrm{K}_{2} \mathrm{CO}_{3}, \mathrm{KHCO}_{3}$, and $\mathrm{KCl}$ treatments were isonatremic $(\mathrm{Na}=0.23 \%, \mathrm{DM}$ basis $)$, concentration of $\mathrm{Na}$ in the rumen increased with $\mathrm{K}_{2} \mathrm{CO}_{3}$ as compared with $\mathrm{KHCO}_{3}(+13 \%)$, and $\mathrm{KCl}(+17 \%)$. As expected, $\mathrm{Cl}$ concentration in the rumen was decreased when cows were fed $\mathrm{K}_{2} \mathrm{CO}_{3}$ compared with $\mathrm{KCl}$ $(-41 \%)$. But surprisingly, despite similar dietary $\mathrm{Cl}$ concentrations, $\mathrm{KHCO}_{3}$ increased $\mathrm{Cl}$ concentration by $19 \%$ as compared with $\mathrm{K}_{2} \mathrm{CO}_{3}$. These results provide further evidence that mineral interactions exist in the rumen, probably as a consequence of transport mechanisms of cations and anions across forestomach epithelia (Leonhard-Marek et al., 2010). Two active pathways contribute to $\mathrm{Na}$ absorption: an electroneutral $\mathrm{Na}^{+} / \mathrm{H}^{+}$ exchange and an electrogenic $\mathrm{Na}^{+}$conductance (Martens and Gäbel, 1988). By incubating ruminal epithelia of sheep, Leonhard-Marek et al. (2007) showed that the presence of $\mathrm{Cl}$ on the luminal side, which corresponds to the rumen cavity, increased electrogenic Na absorption. This increase was mediated via a greater $\mathrm{Cl}^{-} /$ $\mathrm{HCO}_{3}{ }^{-}$or $\mathrm{Cl}^{-} / \mathrm{OH}^{-}$luminal exchange, a higher $\mathrm{pH}$ in the microclimate of the epithelia surface, and a $\mathrm{pH}$ effect on the nonselective cation conductance responsible for $\mathrm{Na}$ absorption (Leonhard-Marek et al., 2007). According to this information, we speculated that lower $\mathrm{Cl}$ concentration observed in the rumen of cows fed $\mathrm{K}_{2} \mathrm{CO}_{3}$ might have decreased $\mathrm{Na}$ transport efficiency, which would explain the greater rumen $\mathrm{Na}$ concentrations observed with $\mathrm{K}_{2} \mathrm{CO}_{3}$ compared with $\mathrm{KCl}$ and $\mathrm{KHCO}_{3}$ treatments.

Magnesium concentration in the rumen was significantly greater when cows received $\mathrm{K}_{2} \mathrm{CO}_{3}$ compared with $\mathrm{Na}_{2} \mathrm{CO}_{3}$ diet (Table 4). Absorption of $\mathrm{Mg}$ in the

Table 4. Rumen $\mathrm{pH}$, volatile fatty acid (VFA), and mineral concentrations of rumen fluid from early-lactation cows receiving high-concentrate diets supplemented with different minerals

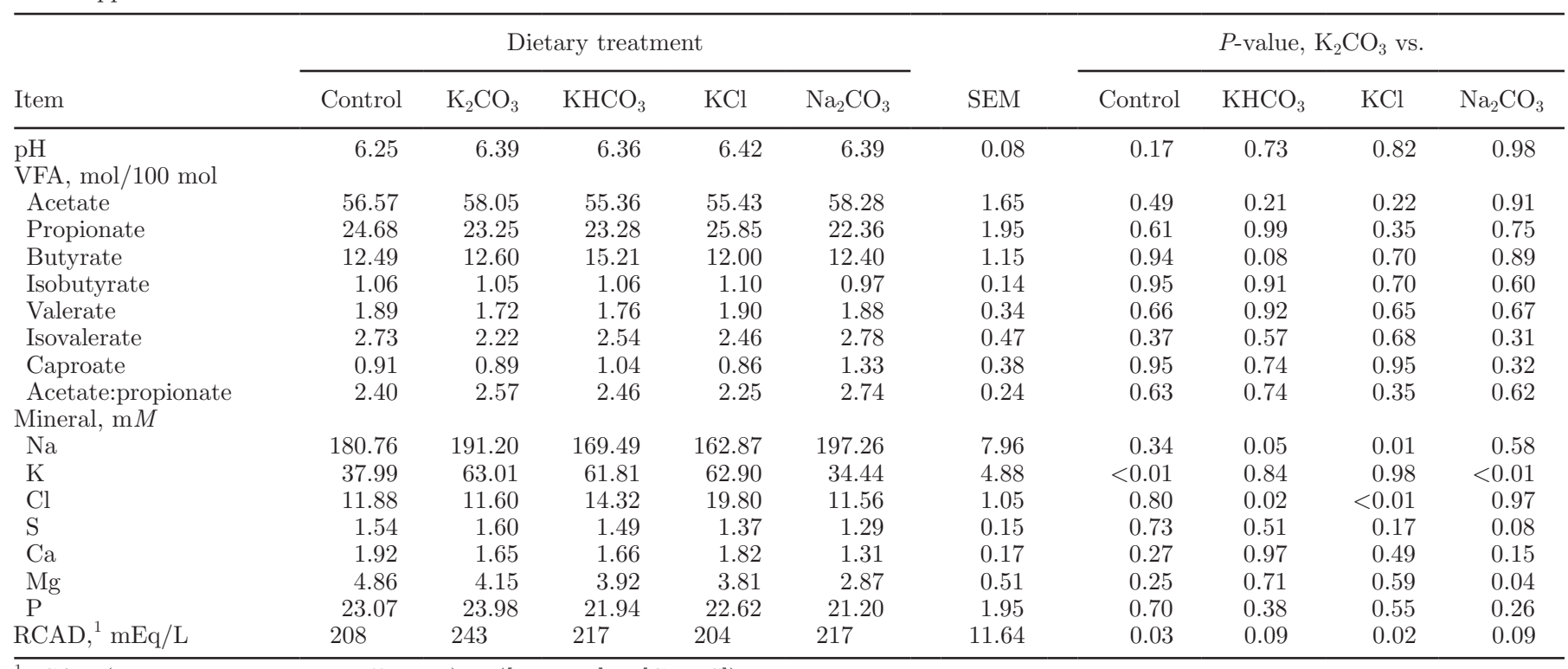

${ }^{1} \mathrm{RCAD}$ (ruminal cation-anion difference $)=([\mathrm{Na}+\mathrm{K}]-[\mathrm{Cl}+\mathrm{S}])$. 
rumen epithelium and subsequent transport to blood (basolateral extrusion) occurs against an electrochemical gradient (Schweigel et al., 2000). An elevated K concentration in the rumen is associated with a decrease in $\mathrm{Mg}$ absorption, whereas higher absorption and transport efficiency for $\mathrm{Mg}$ is reported when $\mathrm{Na}$ concentration in the rumen is increased (Schweigel et al., 2008). No difference was observed between $\mathrm{Mg}$ concentration in the rumen of cows fed control and $\mathrm{K}_{2} \mathrm{CO}_{3}$ treatments. Therefore, the difference in ruminal $\mathrm{Mg}$ concentration observed between cows fed $\mathrm{K}_{2} \mathrm{CO}_{3}$ and $\mathrm{Na}_{2} \mathrm{CO}_{3}$ diets could possibly be a consequence of treatment differences in dietary $\mathrm{Na}$ rather than $\mathrm{K}$ concentrations.

No effect of treatment or treatment $\times$ time interaction, under any of the studied contrasts, was observed on rumen VFA concentrations and $\mathrm{pH}$ (Table 4). Similarly, West et al. (1986) found no difference in rumen $\mathrm{pH}$ when cows were fed diets containing no buffer, $1.8 \%$ $\mathrm{KHCO}_{3}, 1.2 \% \mathrm{~K}_{2} \mathrm{CO}_{3}$, or $1.5 \% \mathrm{NaHCO}_{3}$ (DM basis). Conversely, Fraley et al. (2015) demonstrated that feeding dairy cows with diets containing up to $3.2 \%$ of $\mathrm{K}_{2} \mathrm{CO}_{3}$ increased rumen $\mathrm{pH}$ linearly. In the current experiment, rumen $\mathrm{pH}$ was depressed for all treatments from 0 until $8 \mathrm{~h}$ (6.59 to 6.17) postfeeding (Figure 1).

\section{Systemic Acid-Base Status}

Compared with $\mathrm{K}_{2} \mathrm{CO}_{3}$, blood $\mathrm{K}$ concentration was lower for cows receiving control and $\mathrm{Na}_{2} \mathrm{CO}_{3}$ diets and similar for cows fed $\mathrm{KCl}$ treatment (Table 3). However, despite the isokalemic nature of the diets, cows fed $\mathrm{KHCO}_{3}$ had lower blood $\mathrm{K}$ concentration compared with cows fed $\mathrm{K}_{2} \mathrm{CO}_{3}$ diet. However, to our knowledge, no study has specifically assessed the K bioavailability from these 2 mineral supplements in lactating dairy cows.

Relative to $\mathrm{KCl}$, adding $\mathrm{K}_{2} \mathrm{CO}_{3}$ in the diet tended to increase blood $\mathrm{pH}$, but decreased blood $\mathrm{Cl}$ concentration (Table 3). It is well known that DCAD, has a direct effect on the blood acid-base status, and the metabolic condition of the cows (Block, 1994). Indeed, blood $\mathrm{HCO}_{3}{ }^{-}$concentration and $\mathrm{pH}$ have been shown to increase with increasing DCAD (Roche et al., 2005; Apper-Bossard et al., 2006), whereas decreased DCAD though anionic diets seems to reduce blood $\mathrm{pH}$ (Charbonneau et al., 2009). Therefore, in agreement with Charbonneau et al. (2008), increased dietary concentration of $\mathrm{Cl}$ may explain the tendency for a lower blood $\mathrm{pH}$ found in cows fed $\mathrm{KCl}$, compared with $\mathrm{K}_{2} \mathrm{CO}_{3}$ diet. In contrast, blood anion gap $\left(\mathrm{K}^{+}+\mathrm{Na}^{+}-\mathrm{Cl}^{-}-\right.$ $\mathrm{HCO}_{3}{ }^{-}$), partial pressure of $\mathrm{CO}_{2}$ and $\mathrm{O}_{2}$, concentrations of $\mathrm{HCO}_{3}^{-}$, and hematocrits were similar among treatments.

\section{Milk Production and Composition}

Milk yield tended to decrease and lactose yield decreased when cows were fed $\mathrm{K}_{2} \mathrm{CO}_{3}$ compared with the $\mathrm{KCl}$ diet (Table 2). Because of a high metabolic rate, the cellular environment of cows in lactation tends to be acidotic (Block, 1994). Shire and Beede (2013) suggested that supplementing cationic salts might improve lactation performance by affecting several biological mechanisms such as ruminal buffer ability, blood $\mathrm{pH}$, rumen microbial synthesis, bioactive intermediates of ruminal FA biohydrogenation, and reactions to environmental stressors. Also, it was reported that, when
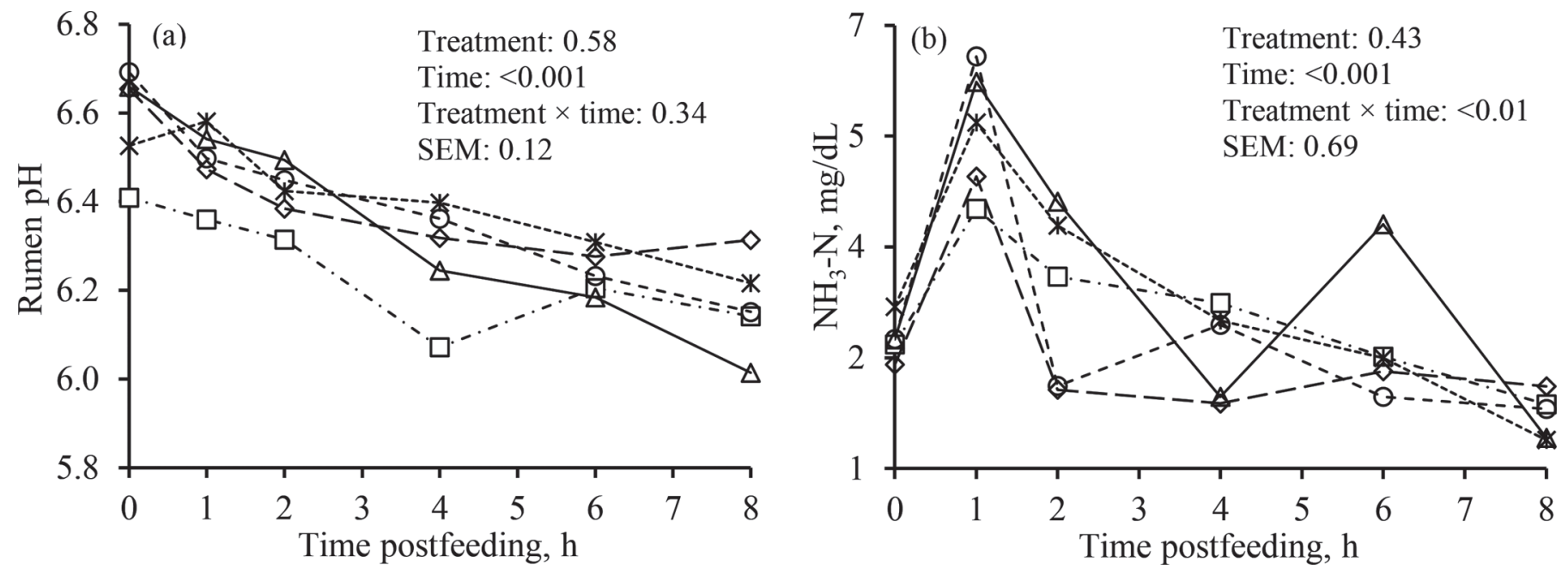

Figure 1. Postfeeding temporal pattern of rumen $\mathrm{pH}(\mathrm{a})$, and $\mathrm{NH}_{3}-\mathrm{N}$ concentration (b) of early-lactation cows fed high-concentrate diets unsupplemented $\left(\square\right.$, control) or supplemented with different minerals $\left(\bigcirc, \mathrm{K}_{2} \mathrm{CO}_{3} ; \Delta, \mathrm{KHCO}_{3} ; \diamond, \mathrm{KCl} ; \mathrm{x}, \mathrm{Na}_{2} \mathrm{CO}_{3}\right)$. 
compared with cows in any other stage of lactation and because they typically receive high-concentrate diets with rapidly degradable starch, early-lactation dairy cows may be more prone to metabolic acidosis (Chan et al., 2005). However, the tendency for a lower milk yield observed in the current study, when early-lactation dairy cows were fed $\mathrm{K}_{2} \mathrm{CO}_{3}$ compared with the $\mathrm{KCl}$ diet, suggests that the effects of mineral supplementation on milk synthesis may involve other factors than DCAD, $\mathrm{K}$ ion, and buffer ability. Although numerically cows fed $\mathrm{KCl}$ as compared with $\mathrm{K}_{2} \mathrm{CO}_{3}$ ate more (1.9 $\mathrm{kg} / \mathrm{d}$ ), this could be partially explain the trend to increase milk yield using $\mathrm{KCl}$ instead of $\mathrm{K}_{2} \mathrm{CO}_{3}$.

The cellular mechanisms involved in the transport of milk constituents out of and across the mammary secretory cell is composed of 4 transcellular and one paracellular known routes (Shennan and Peaker, 2000). These mechanisms require that a constant concentration of gradients in body fluids be maintained to support transport of substrates or metabolites in and out the cells, as well as regulation of osmotic pressure (McDowell, 1992). Mineral concentrations in milk are recognized to reflect their cellular levels (Holt, 1985). Approximately $95 \%$ of milk $\mathrm{K}$ and $\mathrm{Na}$, and $100 \%$ of milk $\mathrm{Cl}$ are found in the aqueous phase, and contribute substantially to milk osmolality (Holt, 1985). However, the mammary gland is able to generate and maintain large $\mathrm{K}, \mathrm{Na}$, and $\mathrm{Cl}$ gradients between milk and plasma (Shennan and Peaker, 2000), suggesting that active ion movements are involved in the secretory mechanisms of milk constituents (Linzell and Peaker, 1971).

In the current study, $\mathrm{Cl}$ concentration was similar in milk from cows fed $\mathrm{K}_{2} \mathrm{CO}_{3}$ and $\mathrm{KCl}$ diets, despite a decreased blood $\mathrm{Cl}$ concentration in cows fed $\mathrm{K}_{2} \mathrm{CO}_{3}$ diet. This result suggests that $\mathrm{Cl}$ concentration in the milieu intérieur (Holmes, 1986) of mammary epithelial cells was maintained constant. The lack of difference in milk $\mathrm{Cl}$ concentration between $\mathrm{K}_{2} \mathrm{CO}_{3}$ and $\mathrm{KCl}$ treatments (Table 2) is in agreement with Bernard's constancy (Holmes, 1986), a mechanism that allows to protect cells from external (blood) conditions to maintain homeostasis of, in this case, the mammary gland.

Shennan and Peaker (2000) suggested that, similar to many secretory epithelia, intracellular accumulation of $\mathrm{Cl}^{-}$, via $\mathrm{Na}^{+}-\mathrm{K}^{+}-\mathrm{Cl}^{-}$cotransport across the basolateral membrane, is the driving force for the secretion of ions and water across the apical membrane of the mammary epithelial cell. More specifically, in mice, it has been previously observed that $\mathrm{Cl}$ transport in $\mathrm{HC} 11$ mammary epithelial cells was achieved by the coordinated action of symporters such as $\mathrm{Na}^{+}-\mathrm{K}^{+}-2 \mathrm{Cl}^{-}$cotransporter isoform 1, cystic fibrosis transmembrane conductance regulator, or $\mathrm{Cl}^{-}$channels 1 and 2 (Selvaraj et al., 2000; Anantamongkol et al., 2012). Accordingly, using a simple linear regression to assess the association between milk yield and milk concentrations of minerals and lactose, we observed a positive relationship between $\mathrm{Cl}$ concentration and milk yield (Figure 2). In contrast, milk yield was not significantly associated with milk concentrations of Na or K. Given that lactose is exclusively synthesized in mammary epithelial cells (Kuhn and Linzell, 1970), lactose synthesis could then be considered to depend mostly on the availability of precursors, the latter being in turn dependent on their transport into the cell and their metabolic fate. A positive relation was also observed between lactose yield and milk $\mathrm{Cl}$ concentration $\left(\mathrm{R}^{2}=0.29\right.$; Figure 2$)$. Previous studies suggested that ions are involved indirectly (Shennan and Peaker, 2000) or directly (McManaman and Neville, 2003) in transport of nutrients across cell membranes, factors that may influence the synthesis of milk. Consequently, we hypothesized that the tendency for increased milk yield and for increased lactose yield when cows were supplemented with $\mathrm{KCl}$ as compared with $\mathrm{K}_{2} \mathrm{CO}_{3}$ could partly be explained by a potential role of $\mathrm{Cl}$ in transport of nutrients and metabolites into and out of mammary epithelial cells.

Despite similar dietary concentrations (Table 1), Ca and $\mathrm{S}$ increased in milk when cows received $\mathrm{K}_{2} \mathrm{CO}_{3}$ as compared with $\mathrm{Na}_{2} \mathrm{CO}_{3}$ diet (Table 2). Both minerals could play an important role in the allostatic process required to maintain ionic equilibrium of the mammary epithelial cell; however, more research is needed to establish the exact mechanism.

Milk fat concentration was increased by $24 \%$ in cows fed $\mathrm{K}_{2} \mathrm{CO}_{3}$ compared with the control diet (Table 2). Consistently, Harrison et al. (2012) reported a 9\% increase in milk fat concentration when cows were fed a diet supplemented with 3.2 vs. $0 \% \mathrm{~K}_{2} \mathrm{CO}_{3}$ (DM basis). Likewise, augmenting dietary $\mathrm{K}_{2} \mathrm{CO}_{3}$ from 0 up to $2.46 \%$ (DM basis) increased milk fat concentration by $10 \%$ (Iwaniuk et al., 2015). However, in contrast with these 2 previous studies, in the current experiment, the $4 \%$ FCM was similar in cows fed $\mathrm{K}_{2} \mathrm{CO}_{3}$ and control diets, possibly due to a numerical decrease in milk yield $(-3.2 \mathrm{~kg} / \mathrm{d})$ when cows were supplemented with $\mathrm{K}_{2} \mathrm{CO}_{3}$.

When compared with the $\mathrm{K}_{2} \mathrm{CO}_{3}$, the control, $\mathrm{KHCO}_{3}$, and $\mathrm{KCl}$ treatments did not affect milk protein concentration or yield. However, cows receiving the $\mathrm{K}_{2} \mathrm{CO}_{3}$ produced milk with a greater protein concentration as compared with cows receiving $\mathrm{Na}_{2} \mathrm{CO}_{3}$ diet. When studying mineral supplements with differing buffering capacities, Mooney and Allen (2007) did not observe any variation in milk protein concentration among cows fed $\mathrm{NaCl}, \mathrm{KCl}, \mathrm{NaHCO}_{3}$, or $\mathrm{KHCO}_{3}$ supplemented diets. However, in a more recent study by Martins et al. (2015), increasing DCAD from -71 to $+290 \mathrm{mEq} / \mathrm{kg}$ of 
(a)

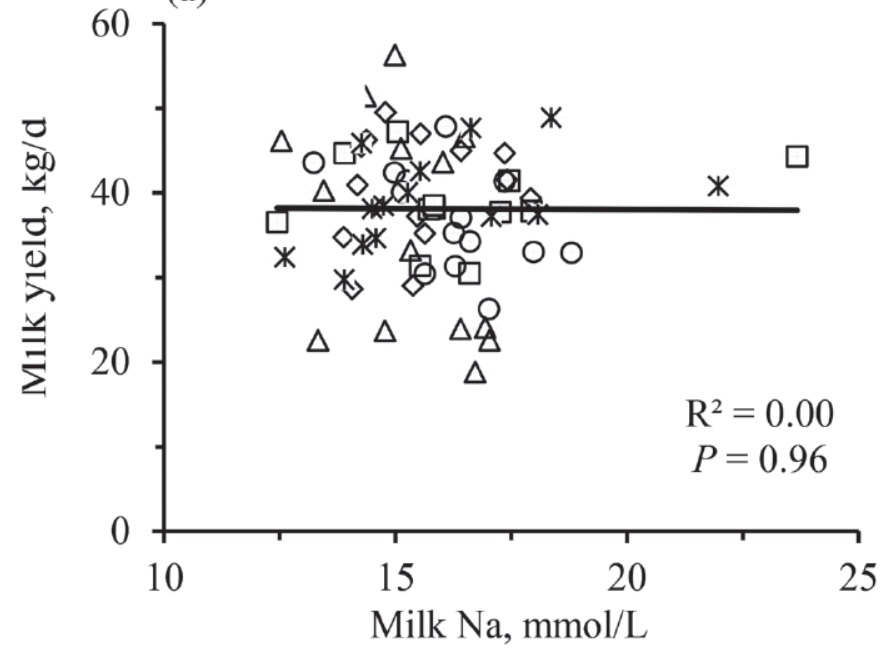

(c)

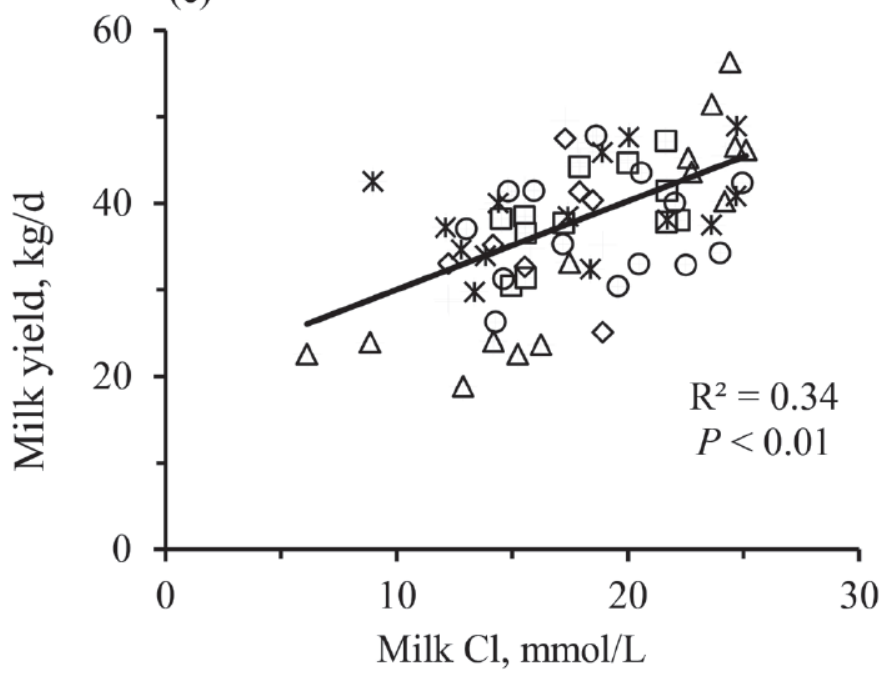

(e)

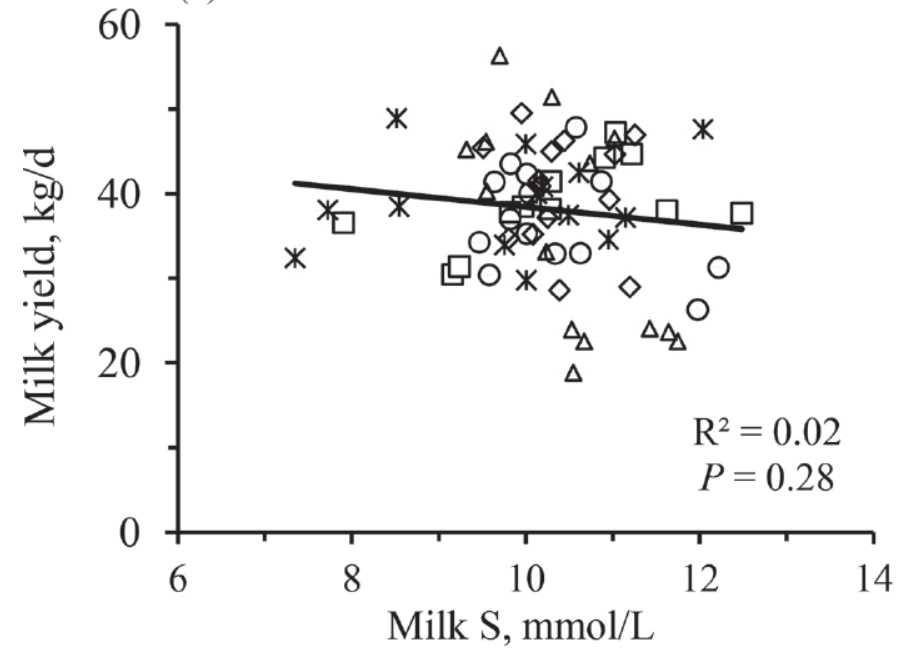

(b)

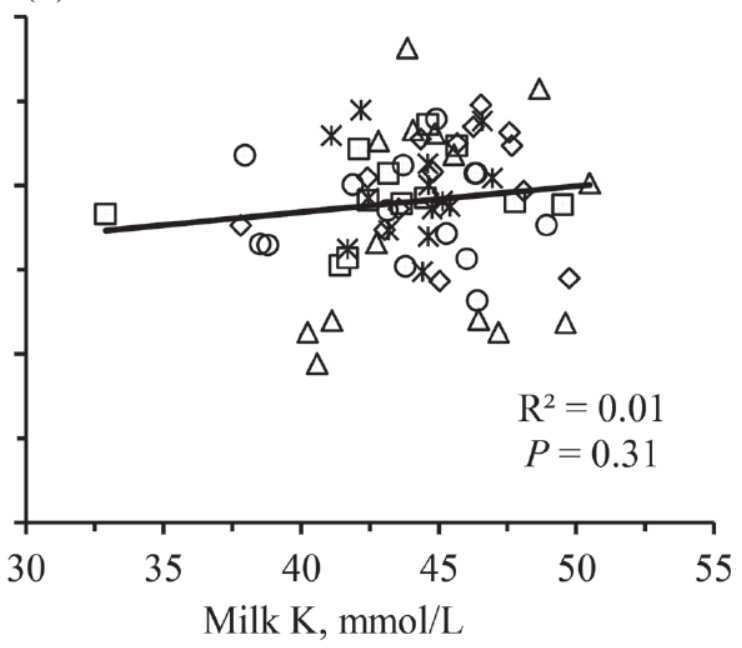

(d)

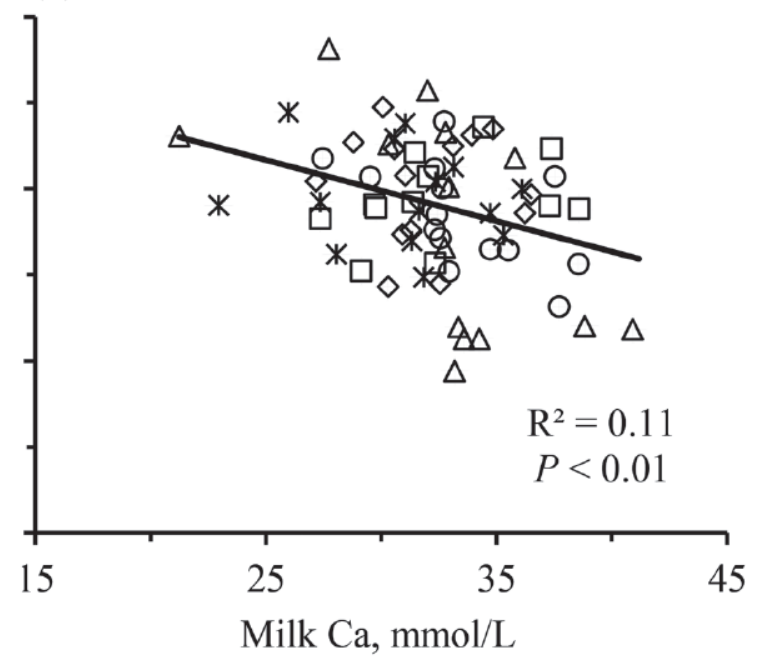

(f)

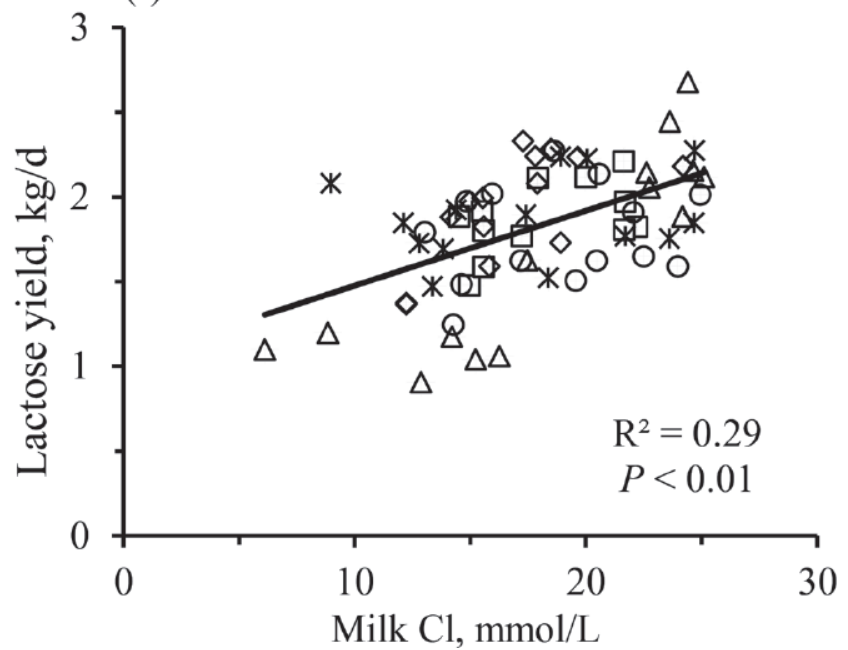

Figure 2. Association between milk yield and milk concentration of (a) sodium, (b) potassium, (c) chlorine, (d) calcium, and (e) sulfur, and between lactose yield and milk concentration of chlorine (f), in early-lactation cows fed high-concentrate diets unsupplemented ( $\square$, control) or supplemented with different minerals $\left(\bigcirc, \mathrm{K}_{2} \mathrm{CO}_{3} ; \Delta, \mathrm{KHCO}_{3} ; \diamond, \mathrm{KCl} ; \mathrm{x}, \mathrm{Na}_{2} \mathrm{CO}_{3}\right)$. 
DM decreased milk protein concentration by $5 \%$. These changes were related to a linear reduction of casein concentration in milk, which was also reported by Harrison et al. (2012). In the current study, DCAD did not affect milk protein synthesis. Moreover, the decrease in milk protein concentration observed with $\mathrm{Na}_{2} \mathrm{CO}_{3}$ compared with $\mathrm{K}_{2} \mathrm{CO}_{3}$ diet did not lead to a decrease in milk protein yield, suggesting a dilution effect due to a numerical increase in milk yield $(+3.6 \mathrm{~kg} / \mathrm{d})$.

Also, one should not ignore that, in the current study, a small number of animals was assigned to each treatment $(\mathrm{n}=7)$ and a substantial variation existed among cows in their response to high-concentrate diets. These conditions could have affected the statistical power of the current experiment, and consequently masked potential treatment effects on milk performance.

\section{Milk Fatty Acid Composition}

Dietary mineral supplementation had some effects on milk FA profile (Table 5). When $\mathrm{Na}_{2} \mathrm{CO}_{3}$ was added to the diet as compared with $\mathrm{K}_{2} \mathrm{CO}_{3}$, milk fat concentrations of trans-6-8 18:1, trans-10 18:1, and cis-6-8 18:1, as well as the trans-10/trans-11 18:1 ratio were increased by $18 \%, 140 \%, 55 \%$, and $106 \%$, respectively. A tendency for similar increases was observed for milk fat concentrations of trans-9 18:1, cis-13 18:1, and cis-14 18:1, whereas a tendency for a decrease in trans-13-14 18:1 was observed when $\mathrm{Na}_{2} \mathrm{CO}_{3}$ was compared with the $\mathrm{K}_{2} \mathrm{CO}_{3}$ diet. Ruminal bacteria are largely responsible for rumen biohydrogenation of PUFA (Harfoot, 1978). It may be possible that differences in cation source $(\mathrm{K}$ vs. Na) affected a niche of bacteria involved in this process, leading to differences in milk fat concentrations of various biohydrogenation intermediates. When comparing cows supplemented with $\mathrm{KCl}$ and $\mathrm{K}_{2} \mathrm{CO}_{3}$, along with a decrease in DCAD, milk fat concentrations of trans-15 18:1 (+13\%), cis-6-8 18:1 (+44\%), cis13 18:1 (+60\%), and cis-15 18:1 (+25\%; tendency), as well as the trans-10/trans-11 18:1 ratio (+85\%), were increased with $\mathrm{KCl}$.

Moreover, a numerical $(-44 \%)$ yet not significant $(P$ $=0.16$ ) decrease in milk fat concentration of trans-10 18:1 was observed when $\mathrm{K}_{2} \mathrm{CO}_{3}$ was compared with the $\mathrm{KCl}$ diet. When DCAD was increased (from 320 to $530 \mathrm{mEq} / \mathrm{kg}$ of $\mathrm{DM}$ ) through $\mathrm{K}_{2} \mathrm{CO}_{3}$ supplementation, Harrison et al. (2012) observed a $40 \%$ decrease in concentration of trans-10 18:1 in milk fat of dairy cows. In contrast, other studies showed no effect on milk trans-10 18:1 when mineral supplements were combined to achieve different DCAD (Roche et al., 2005; Apper-Bossard et al., 2006). Discrepancies between studies could be related to different factors such as levels of mineral supplementation, basal diet compo- sition, and individual variation in animal response to high-concentrate diets.

Additionally, a decreased concentration of anteiso 15:0 in milk fat was observed when $\mathrm{K}_{2} \mathrm{CO}_{3}$ was added to the diet, compared with control, $\mathrm{KHCO}_{3}$, or $\mathrm{Na}_{2} \mathrm{CO}_{3}$. Lipid membrane composition of ruminal bacteria is characterized by a large proportion of branched-chain FA (iso 15:0, iso 17:0, anteiso 15:0, anteiso 17:0; Vlaeminck et al., 2005). In particular, amylolytic bacteria are reported to have greater proportions of anteiso FA in their lipid membranes (Vlaeminck et al., 2006). Diets with high inclusion of concentrate, which increase the relative abundance of amylolytic bacteria in the rumen, can be expected to lead to greater proportions of rumen anteiso FA and, consequently, to greater concentrations of these FA in milk fat (Vlaeminck et al., 2006).

A decrease in melting point of bacterial membrane lipid composition has been previously reported as a mechanism to modulate and maintain membrane fluidity and transport functions (homeoviscous adaptation) in response to $\mathrm{pH}$ (Giotis et al., 2007) and osmotic stress (Chihib et al., 2003). Because anteiso FA have low melting points compared with iso FA, synthesis of anteiso FA is stimulated under stress conditions (Annous et al., 1997). Consequently, it could be suggested that adding $\mathrm{K}_{2} \mathrm{CO}_{3}$ to the diet, compared with other source of minerals, induced modifications in the rumen environment, which prevented bacteria to resort to modulation of their membrane FA profile to resist stressing conditions normally related to high-concentrate diets.

Of note, when cows were fed the $\mathrm{K}_{2} \mathrm{CO}_{3}$ diet, milk fat concentrations of anteiso 15:0 and trans-10, cis-12 18:2 were positively correlated (Figure 3). Because concentrations of milk branched-chain FA were not determined when mineral supplementation was evaluated in earlier studies, the link between anteiso 15:0 and trans-10,cis-12 18:2 has not been previously reported. Further research is then needed to elucidate the potential link between these 2 FA involved in rumen lipid metabolism and the effect of mineral supplementation on this relationship.

\section{CONCLUSIONS}

In the current experiment, and as opposed to previous studies, supplementing high-concentrate diets with $\mathrm{K}_{2} \mathrm{CO}_{3}$ did not increase milk or milk fat yield in earlylactation cows. Adding $\mathrm{K}_{2} \mathrm{CO}_{3}$ even led to a tendency for a decreased milk yield when compared with $\mathrm{KCl}$. Overall, using $\mathrm{K}_{2} \mathrm{CO}_{3}$ as a mineral supplement to modulate DCAD, $\mathrm{K}$ ion, or buffer ability of diets, affected the rumen environment, but did not stimulate synthesis of milk components. Our results suggest that increasing 
Table 5. Fatty acid composition of milk fat from early-lactation cows receiving high-concentrate diets supplemented with different minerals

\begin{tabular}{|c|c|c|c|c|c|c|c|c|c|c|}
\hline Item, \% & \multicolumn{5}{|c|}{ Dietary treatment } & SEM & \multicolumn{4}{|c|}{$P$-value, $\mathrm{K}_{2} \mathrm{CO}_{3}$ vs. } \\
\hline 4:0 & 2.643 & 2.64 & 2.648 & 2.682 & 2.853 & 0.126 & 0.99 & 0.97 & 0.82 & 0.24 \\
\hline 8:0 & 1.103 & 1.185 & 1.108 & 1.095 & 1.170 & 0.064 & 0.39 & 0.41 & 0.34 & 0.88 \\
\hline 10:0 & 2.882 & 3.083 & 2.785 & 2.700 & 2.964 & 0.206 & 0.50 & 0.32 & 0.20 & 0.69 \\
\hline 10:1 & 0.225 & 0.258 & 0.252 & 0.229 & 0.225 & 0.018 & 0.17 & 0.81 & 0.20 & 0.17 \\
\hline 11:0 & 0.099 & 0.109 & 0.093 & 0.109 & 0.094 & 0.023 & 0.74 & 0.57 & 1.00 & 0.60 \\
\hline anteiso 13:0 & 0.013 & 0.014 & 0.013 & 0.011 & 0.016 & 0.001 & 0.69 & 0.78 & 0.34 & 0.28 \\
\hline $12: 1$ & 0.092 & 0.104 & 0.102 & 0.086 & 0.088 & 0.009 & 0.29 & 0.89 & 0.13 & 0.19 \\
\hline $13: 0$ & 0.159 & 0.150 & 0.136 & 0.158 & 0.141 & 0.028 & 0.78 & 0.72 & 0.82 & 0.80 \\
\hline iso $14: 0$ & 0.053 & 0.062 & 0.050 & 0.057 & 0.075 & 0.012 & 0.50 & 0.38 & 0.74 & 0.30 \\
\hline 14:0 & 11.506 & 10.765 & 10.775 & 10.193 & 11.356 & 0.376 & 0.17 & 0.98 & 0.28 & 0.27 \\
\hline cis-9 14:1 & 0.875 & 0.871 & 0.860 & 0.945 & 0.827 & 0.067 & 0.96 & 0.41 & 0.90 & 0.64 \\
\hline $16: 0$ & 29.428 & 29.351 & 30.932 & 28.757 & 28.48 & 0.894 & 0.94 & 0.15 & 0.58 & 0.43 \\
\hline trans-9 16:1 & 0.031 & 0.033 & 0.039 & 0.031 & 0.063 & 0.014 & 0.93 & 0.76 & 0.95 & 0.13 \\
\hline cis-9 16:1 & 1.135 & 1.242 & 1.368 & 1.297 & 1.205 & 0.087 & 0.39 & 0.31 & 0.65 & 0.77 \\
\hline cis-11 16:1 & 0.038 & 0.039 & 0.031 & 0.043 & 0.035 & 0.004 & 0.81 & 0.19 & 0.53 & 0.42 \\
\hline cis-13 16:1 & 0.185 & 0.206 & 0.203 & 0.179 & 0.169 & 0.019 & 0.34 & 0.89 & 0.23 & 0.11 \\
\hline iso $17: 0^{1}$ & 0.257 & 0.236 & 0.264 & 0.266 & 0.260 & 0.017 & 0.31 & 0.16 & 0.18 & 0.26 \\
\hline anteiso $17: 0^{2}$ & 0.362 & 0.345 & 0.393 & 0.392 & 0.396 & 0.021 & 0.59 & 0.14 & 0.12 & 0.11 \\
\hline $17: 0$ & 0.254 & 0.238 & 0.255 & 0.274 & 0.243 & 0.021 & 0.60 & 0.56 & 0.23 & 0.86 \\
\hline cis-7 17:0 & 0.013 & 0.014 & 0.014 & 0.014 & 0.013 & 0.001 & 0.78 & 0.68 & 0.59 & 0.44 \\
\hline cis-8 17:1 & 0.009 & 0.010 & 0.009 & 0.010 & 0.010 & 0.001 & 0.39 & 0.43 & 0.79 & 0.88 \\
\hline cis-9 17:1 & 0.097 & 0.099 & 0.102 & 0.115 & 0.106 & 0.011 & 0.86 & 0.87 & 0.32 & 0.66 \\
\hline iso $18: 0$ & 0.017 & 0.015 & 0.017 & 0.019 & 0.021 & 0.002 & 0.75 & 0.59 & 0.41 & 0.20 \\
\hline $18: 0$ & 6.463 & 6.638 & 6.015 & 6.775 & 6.541 & 0.523 & 0.78 & 0.32 & 0.82 & 0.87 \\
\hline trans-4 18:1 & 0.016 & 0.018 & 0.016 & 0.016 & 0.020 & 0.002 & 0.57 & 0.61 & 0.66 & 0.44 \\
\hline cis-6-8 18:1 & 0.118 & 0.085 & 0.116 & 0.125 & 0.139 & 0.012 & 0.05 & 0.06 & 0.03 & $<0.01$ \\
\hline cis-9-10 18:1 & 14.993 & 15.25 & 14.646 & 16.401 & 15.363 & 0.961 & 0.85 & 0.64 & 0.37 & 0.93 \\
\hline cis-11 18:1 & 0.711 & 0.649 & 0.569 & 0.782 & 0.623 & 0.064 & 0.48 & 0.37 & 0.13 & 0.77 \\
\hline cis-12 18:1 & 0.206 & 0.219 & 0.212 & 0.237 & 0.229 & 0.015 & 0.49 & 0.70 & 0.39 & 0.61 \\
\hline cis-13 18:1 & 0.049 & 0.049 & 0.045 & 0.081 & 0.075 & 0.011 & 0.98 & 0.78 & 0.03 & 0.07 \\
\hline cis-14 18:1 & 0.042 & 0.036 & 0.038 & 0.040 & 0.047 & 0.004 & 0.36 & 0.67 & 0.48 & 0.09 \\
\hline cis-15 18:1 & 0.038 & 0.036 & 0.044 & 0.048 & 0.047 & 0.005 & 0.70 & 0.23 & 0.08 & 0.11 \\
\hline cis-9,trans-12 18:2 & 0.045 & 0.042 & 0.039 & 0.046 & 0.044 & 0.002 & 0.42 & 0.40 & 0.33 & 0.66 \\
\hline trans-9,trans-12 18:2 & 0.011 & 0.012 & 0.010 & 0.010 & 0.012 & 0.001 & 0.64 & 0.53 & 0.38 & 0.99 \\
\hline cis-9,trans-13 18:2 & 0.277 & 0.258 & 0.256 & 0.259 & 0.264 & 0.023 & 0.55 & 0.93 & 0.99 & 0.84 \\
\hline trans-8, cis-13 18:2 & 0.082 & 0.074 & 0.082 & 0.082 & 0.080 & 0.004 & 0.26 & 0.25 & 0.23 & 0.36 \\
\hline trans-9,cis-12 18:2 & 0.022 & 0.019 & 0.023 & 0.025 & 0.021 & 0.001 & 0.19 & 0.13 & 0.01 & 0.47 \\
\hline trans-11,cis-15 18:2 & 0.035 & 0.030 & 0.037 & 0.038 & 0.047 & 0.006 & 0.35 & 0.16 & 0.09 & $<0.01$ \\
\hline cis-9,12 18:2 & 2.046 & 2.152 & 2.028 & 2.278 & 2.153 & 0.185 & 0.34 & 0.27 & 0.27 & 0.99 \\
\hline cis-9,trans-11 18:2 & 0.263 & 0.249 & 0.295 & 0.282 & 0.279 & 0.034 & 0.64 & 0.12 & 0.27 & 0.31 \\
\hline trans-10, cis-12 18:2 & 0.012 & 0.015 & 0.013 & 0.014 & 0.012 & 0.001 & 0.22 & 0.30 & 0.73 & 0.14 \\
\hline cis-9,12,15 18:3 & 0.278 & 0.268 & 0.275 & 0.274 & 0.274 & 0.030 & 0.80 & 0.87 & 0.89 & 0.88 \\
\hline cis-6,9,12 18:3 & 0.032 & 0.036 & 0.031 & 0.031 & 0.033 & 0.003 & 0.17 & 0.12 & 0.12 & 0.33 \\
\hline cis-9,trans-11,cis-15 18:3 & 0.020 & 0.017 & 0.022 & 0.024 & 0.019 & 0.002 & 0.21 & 0.05 & 0.01 & 0.59 \\
\hline cis-6,9,12,15 18:4 & 0.022 & 0.018 & 0.019 & 0.021 & 0.024 & 0.003 & 0.37 & 0.94 & 0.53 & 0.17 \\
\hline 19:0 & 0.065 & 0.068 & 0.061 & 0.061 & 0.066 & 0.005 & 0.70 & 0.37 & 0.38 & 0.76 \\
\hline $20: 0$ & 0.095 & 0.098 & 0.087 & 0.097 & 0.094 & 0.006 & 0.70 & 0.17 & 0.87 & 0.65 \\
\hline
\end{tabular}


Table 5 (Continued). Fatty acid composition of milk fat from early-lactation cows receiving high-concentrate diets supplemented with different minerals

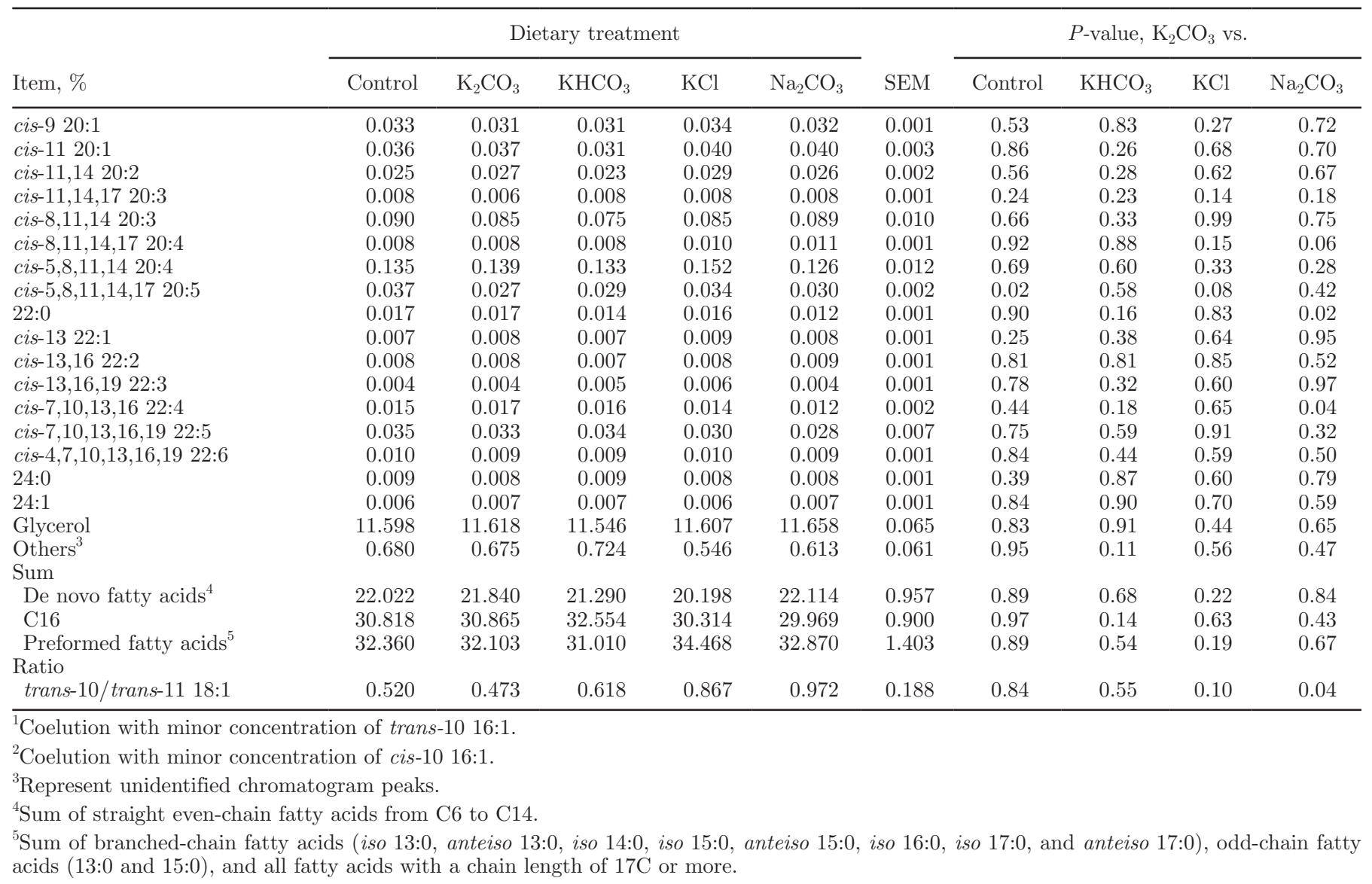

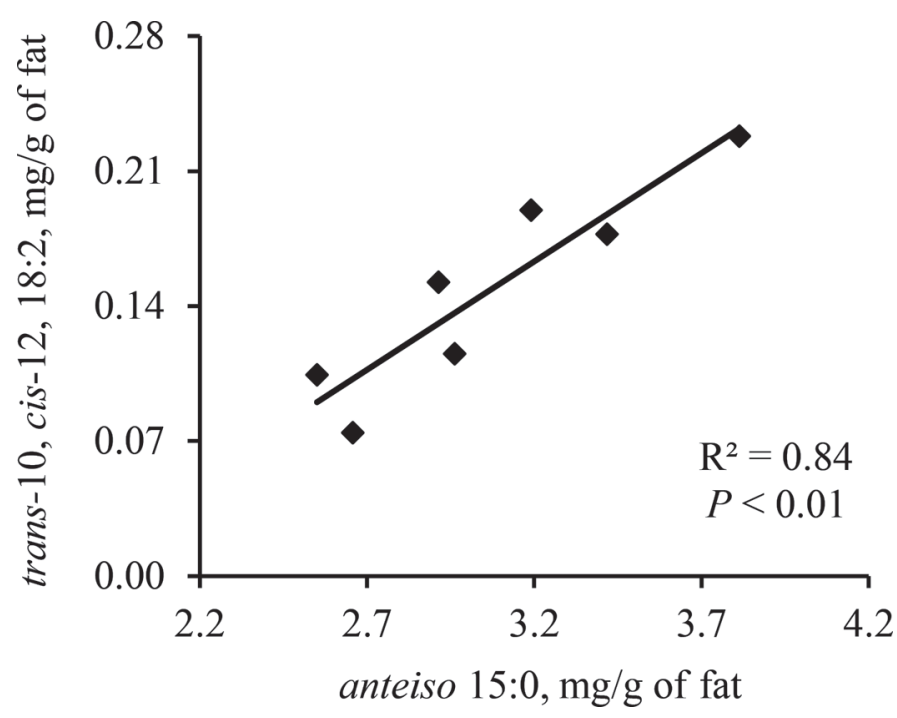

Figure 3. Association between milk fat concentration of trans-10, cis-12 18:2, and anteiso 15:0 in early-lactation cows fed a high-concentrate diet containing $1.8 \%$ of $\mathrm{K}_{2} \mathrm{CO}_{3}$ (DM basis). dietary $\mathrm{K}$ through the addition of $\mathrm{K}_{2} \mathrm{CO}_{3}$ could lead to a disequilibrium in cellular ion composition that can impair nutrient transport into and out of the mammary epithelial cells, and consequently affect milk synthesis. Further research is needed to establish under which conditions dietary $\mathrm{K}_{2} \mathrm{CO}_{3}$ supplementation can contribute to rumen stability of early-lactation cows, and to determine how dietary mineral supplementation affects the metabolism of mammary epithelial cells.

\section{ACKNOWLEDGMENTS}

This experiment was funded through the Programme de recherche en partenariat pour l'innovation en production et en transformation laitières supported by Agriculture and Agri-Food Canada, the Fonds de Recherche du Québec-Nature et Technologies (FRQNT; Québec, QC, Canada), the Ministère de l'Agriculture, des Pêcheries et de l'Alimentation du Québec, and Novalait Inc. The authors thank Gilles Bélanger, Danielle Mongrain, and Mario Laterrière from Agriculture and Agri-Food Canada, (Québec, QC, Canada), as well as 
Micheline Gingras and Yolaine Lebeuf from Université Laval (Québec, QC, Canada) for professional and technical assistance, Yan Martel-Kennes and Annie Dumas for their help in organizing the experiment at the farm, and André Perreault, Philippe Cantin, Denis Lefebvre, and Sébastien Coursol for all their work in the barn at the Centre de Recherche en Sciences Animales de Deschambault (Deschambault, QC, Canada).

\section{REFERENCES}

Adriano, D. C., and H. E. Doner. 1982. Bromine, chlorine, and fluorine. Pages 449-483 in Methods of Soil Analysis. Part 2. Chemical and Microbiological Properties. 2nd ed. A. L. Page, R. H. Miller, and D. R. Keeney, ed. ASA, SSSA Inc., Madison, WI.

Anantamongkol, U., M. Ao, J. Sarathy (nee Venkatasubramanian), Y. S. Devi, N. Krishnamra, and M. C. Rao. 2012. Prolactin and dexamethasone regulate second messenger-stimulated $\mathrm{Cl}^{-}$secretion in mammary epithelia. J. Signal Transduct. 2012:192142. https:// doi.org/10.1155/2012/192142.

Annous, B. A., L. A. Becker, D. O. Bayles, D. P. Labeda, and B. J. Wilkinson. 1997. Critical role of anteiso-C15:0 fatty acid in the growth of Listeria monocytogenes at low temperatures. Appl. Environ. Microbiol. 63:3887-3894.

AOAC International. 2000. Official Methods of Analysis. 16th ed. AOAC International, Gaithersburg, MD.

AOAC International. 2012. Official Methods of Analysis. 19th ed. AOAC International, Arlington, VA.

Apper-Bossard, E., P. Faverdin, F. Meschy, and J. L. Peyraud. 2010 Effects of dietary cation-anion difference on ruminal metabolism and blood acid-base regulation in dairy cows receiving 2 contrasting levels of concentrate in diets. J. Dairy Sci. 93:4196-4210. https://doi.org/10.3168/jds.2009-2975.

Apper-Bossard, E., J. L. Peyraud, P. Faverdin, and F. Meschy. 2006. Changing dietary cation-anion difference for dairy cows fed with two contrasting levels of concentrate in diets. J. Dairy Sci. 89:749 760. https://doi.org/10.3168/jds.S0022-0302(06)72136-1.

Baumgard, L. H., B. A. Corl, D. A. Dwyer, A. Saebø, and D. E. Bauman. 2000. Identification of the conjugated linoleic acid isomer that inhibits milk fat synthesis. Am. J. Physiol. Regul. Integr. Comp. Physiol. 278:R179-R184.

Block, E. 1994. Manipulation of dietary cation-anion difference on nutritionally related production diseases, productivity, and metabolic responses of dairy cows. J. Dairy Sci. 77:1437-1450. https://doi. org/10.3168/jds.S0022-0302(94)77082-X.

Boivin, M., R. Gervais, and P. Y. Chouinard. 2013. Effect of grain and forage fractions of corn silage on milk production and composition in dairy cows. Animal 7:245-254. https://doi.org/10.1017/ S1751731112001486.

Canadian Council on Animal Care. 1993. Guide to the Care and Use of Experimental Animals. Vol. 1. 2nd ed. CCAC, Ottawa, ON, Canada.

Chan, P. S., J. W. West, J. K. Bernard, and J. M. Fernandez. 2005. Effects of dietary cation-anion difference on intake, milk yield, and blood components of the early lactation cow. J. Dairy Sci. 88:43844392. https://doi.org/10.3168/jds.S0022-0302(05)73125-8.

Charbonneau, E., P. Y. Chouinard, G. F. Tremblay, G. Allard, and D. Pellerin. 2008. Hay to reduce dietary cation-anion difference for dry dairy cows. J. Dairy Sci. 91:1585-1596. https://doi. org/10.3168/jds.2007-0775.

Charbonneau, E., P. Y. Chouinard, G. F. Tremblay, G. Allard, and D. Pellerin. 2009. Timothy silage with low dietary cation-anion difference fed to nonlactating cows. J. Dairy Sci. 92:2067-2077. https:// doi.org/10.3168/jds.2008-1569.

Chihib, N.-E., M. Ribeiro da Silva, G. Delattre, M. Laroche, and M. Federighi. 2003. Different cellular fatty acid pattern behaviours of two strains of Listeria monocytogenes Scott A and CNL 895807 under different temperature and salinity conditions. FEMS Micro- biol. Lett. 218:155-160. https://doi.org/10.1111/j.1574-6968.2003. tb11512.x.

Chouinard, P. Y., J. Lévesque, V. Girard, and G. J. Brisson. 1997. Dietary soybeans extruded at different temperatures: Milk composition and in situ fatty acid reactions. J. Dairy Sci. 80:2913-2924. https://doi.org/10.3168/jds.S0022-0302(97)76257-X.

Davis, C. L., and R. E. Brown. 1970. Low-fat milk syndrome. Pages 545-565 in Physiology of Digestion and Metabolism in the Ruminant. A. T. Phillipson, ed. Oriel, Newcastle Upon Tyne, UK.

Emery, R. S., and L. D. Brown. 1961. Effect of feeding sodium and potassium bicarbonate on milk fat, rumen $\mathrm{pH}$, and volatile fatty acid production. J. Dairy Sci. 44:1899-1902. https://doi.org/10.3168/ jds.S0022-0302(61)89981-5.

Erdman, R. A. 1988. Dietary buffering requirements of the lactating dairy cow: A review. J. Dairy Sci. 71:3246-3266. https://doi org/10.3168/jds.S0022-0302(88)79930-0.

Fauteux, M.-C., R. Gervais, D. E. Rico, Y. Lebeuf, and P. Y. Chouinard. 2016. Production, composition, and oxidative stability of milk highly enriched in polyunsaturated fatty acids from dairy cows fed alfalfa protein concentrate or supplemental vitamin E. J. Dairy Sci. 99:4411-4426. https://doi.org/10.3168/jds.2015-10722.

Fraley, S. E., M. B. Hall, and T. D. Nennich. 2015. Effect of variable water intake as mediated by dietary potassium carbonate supplementation on rumen dynamics in lactating dairy cows. J. Dairy Sci. 98:3247-3256. https://doi.org/10.3168/jds.2014-8557.

Gäbel, G., M. Bestmann, and H. Martens. 1991. Influences of diet, short-chain fatty acids, lactate and chloride on bicarbonate movement across the reticulo-rumen wall of sheep. J. Vet. Med. A Physiol. Pathol. Clin. Med. 38:523-529. https://doi. org/10.1111/j.1439-0442.1991.tb01043.x.

Gaucheron, F., Y. Le Graët, M. Piot, and E. Boyaval. 1996. Determination of anions of milk by ion chromatography. Lait 76:433-443. https://doi.org/10.1051/lait:1996533.

Giotis, E. S., D. A. McDowell, I. S. Blair, and B. J. Wilkinson. 2007. Role of branched-chain fatty acids in $\mathrm{pH}$ stress tolerance in Listeria monocytogenes. Appl. Environ. Microbiol. 73:997-1001.

Grummer, R. R. 1993. Etiology of lipid-related metabolic disorders in periparturient dairy cows. J. Dairy Sci. 76:3882-3896. https://doi. org/10.3168/jds.S0022-0302(93)77729-2 http://dx.doi.

Hall, M. B. 2009. Determination of starch, including maltooligosaccharides, in animal feeds: Comparison of methods and a method recommended for AOAC collaborative study. J. AOAC Int. 92:42-49.

Harfoot, C. G. 1978. Lipid metabolism in the rumen. Prog. Lipid Res 17:21-54. https://doi.org/10.1016/0079-6832(78)90004-6.

Harrison, J., R. White, R. Kincaid, E. Block, T. Jenkins, and N. StPierre. 2012. Effectiveness of potassium carbonate sesquihydrate to increase dietary cation-anion difference in early lactation cows. J. Dairy Sci. 95:3919-3925. https://doi.org/10.3168/jds.2011-4840.

Hoffmann, E. K., I. H. Lambert, and S. F. Pedersen. 2009. Physiology of cell volume regulation in vertebrates. Physiol. Rev. 89:193-277. https://doi.org/10.1152/physrev.00037.2007.

Holmes, F. L. 1986. Claude Bernard, the "milieu intérieur", and regulatory physiology. Hist. Philos. Life Sci. 8:3-25.

Holt, C. 1985. The milk salts: their secretion, concentrations and physical chemistry. Pages 143-181 in Developments in Dairy Chemistry - 3 Lactose and Minor Constituents. P. F. Fox, ed. Springer, Barking, Essex, England.

Hu, W., L. Kung, and M. R. Murphy. 2007a. Relationships between dry matter intake and acid-base status of lactating dairy cows as manipulated by dietary cation-anion difference. Anim. Feed Sci. Technol. 136:216-225. https://doi.org/10.1016/j. anifeedsci.2006.09.013.

Hu, W., M. R. Murphy, P. D. Constable, and E. Block. 2007b. Dietary cation-anion difference effects on performance and acid-base status of dairy cows postpartum. J. Dairy Sci. 90:3367-3375. https://doi. org $/ 10.3168 /$ jds.2006-515.

Iwaniuk, M. E., A. E. Weidman, and R. A. Erdman. 2015. The effect of dietary cation-anion difference concentration and cation source on milk production and feed efficiency in lactating dairy cows. J. Dairy Sci. 98:1950-1960. https://doi.org/10.3168/jds.2014-8704. 
Jenkins, T. C., W. C. Bridges Jr., J. H. Harrison, and K. M. Young. 2014. Addition of potassium carbonate to continuous cultures of mixed ruminal bacteria shifts volatile fatty acids and daily production of biohydrogenation intermediates. J. Dairy Sci. 97:975-984. https://doi.org/10.3168/jds.2013-7164.

Johnson, G. V., and P. E. Fixen. 1990. Testing soils for sulfur, boron, molybdenum, and chlorine. Pages $265-273$ in Soil Testing and Plant Analysis. Vol. 3. R. L. Westerman, ed. Soil Science Society of America, Madison, WI.

Krause, K. M., and G. R. Oetzel. 2006. Understanding and preventing subacute ruminal acidosis in dairy herds: A review. Anim. Feed Sci. Technol. 126:215-236. https://doi.org/10.1016/j. anifeedsci.2005.08.004.

Kuhn, N. J., and J. L. Linzell. 1970. Measurement of the quantity of lactose passing into mammary venous plasma and lymph in goats and in a cow. J. Dairy Res. 37:203-208. doi:10.1017/ S002202990001325X.

Lachat Instruments. 2013. Methods list for automated ion analyzers (flow injection analyses - ion chromatography). Accessed Jun. 20, 2016. http://www.lachatinstruments.com/download/LL022Rev-7.pdf.

Leonhard-Marek, S., G. Becker, G. Breves, and B. Schröder. 2007. Chloride, gluconate, sulfate, and short-chain fatty acids affect calcium flux rates across the sheep forestomach epithelium. J. Dairy Sci. 90:1516-1526. https://doi.org/10.3168/jds.S00220302(07)71637-5.

Leonhard-Marek, S., F. Stumpff, and H. Martens. 2010. Transport of cations and anions across forestomach epithelia: Conclusions from in vitro studies. Animal 4:1037-1056. https://doi.org/10.1017/ S1751731110000261

Linzell, J. L., and M. Peaker. 1971. Intracellular concentrations of sodium, potassium and chloride in the lactating mammary gland and their relation to the secretory mechanism. J. Physiol. 216:683-700. https://doi.org/10.1113/jphysiol.1971.sp009547.

Liu, L. 1998. Determination of chloride in plant tissue. Pages 111-113 in Handbook of Reference Methods for Plant Analysis. Y. P. Kalra, ed. CRC Press, Boca Raton, FL.

Martens, H., and G. Gabel. 1988. Transport of $\mathrm{Na}$ and $\mathrm{Cl}$ across the epithelium of ruminant forestomachs: Rumen and omasum. A review. Comp. Biochem. Physiol. A Physiol. 90:569-575. https://doi. org/10.1016/0300-9629(88)90669-X.

Martins, C. M. M. R., M. A. Arcari, K. C. Welter, A. S. Netto, C. A. F. Oliveira, and M. V. Santos. 2015. Effect of dietary cationanion difference on performance of lactating dairy cows and stability of milk proteins. J. Dairy Sci. 98:2650-2661. https://doi. org/10.3168/jds.2014-8926.

McDowell, L. R. 1992. Potassium. Pages 129-149 in Minerals in Animal and Human Nutrition. Academic Press Inc., San Diego, CA.

McManaman, J. L., and M. C. Neville. 2003. Mammary physiology and milk secretion. Adv. Drug Deliv. Rev. 55:629-641. https://doi. org/10.1016/S0169-409X(03)00033-4.

Mills, H. A., and J. B. Jones Jr. 1996. Plant Analysis Handbook II: A Practical Sampling, Preparation, Analysis, and Interpretation Guide. MicroMacro Publishing Inc., Athens, GA

Mooney, C. S., and M. S. Allen. 2007. Effect of dietary strong ions on chewing activity and milk production in lactating dairy cows. J. Dairy Sci. 90:5610-5618. https://doi.org/10.3168/jds.2007-0008.
Nocek, J. E. 1997. Bovine acidosis: Implications on laminitis. J. Dairy Sci. 80:1005-1028. https://doi.org/10.3168/jds.S00220302(97)76026-0.

Novozamsky, I., R. van Eck, J. C. van Schouwenburg, and I. Walinga. 1974. Total nitrogen determination in plant material by means of the indophenol-blue method. Neth. J. Agric. Sci. 22:3-5.

NRC. 2001. Nutrient Requirements of Dairy Cattle. 7th rev. ed. Natl. Acad. Press, Washington, DC.

Perfield, J. W., II, A. L. Lock, J. M. Griinari, A. Sæbø, P. Delmonte, D. A. Dwyer, and D. E. Bauman. 2007. Trans-9, cis-11 conjugated linoleic acid reduces milk fat synthesis in lactating dairy cows. J. Dairy Sci. 90:2211-2218. https://doi.org/10.3168/jds.2006-745.

Roche, J. R., S. Petch, and J. K. Kay. 2005. Manipulating the dietary cation-anion difference via drenching to early-lactation dairy cows grazing pasture. J. Dairy Sci. 88:264-276. https://doi.org/10.3168/ jds.S0022-0302(05)72684-9.

Schweigel, M., M. Kolisek, Z. Nikolic, and J. Kuzinski. 2008. Expression and functional activity of the $\mathrm{Na} / \mathrm{Mg}$ exchanger, TRPM7 and MagT1 are changed to regulate $\mathrm{Mg}$ homeostasis and transport in rumen epithelial cells. Magnes. Res. 21:118-123. https://doi. org $/ 10.1684 / \mathrm{mrh} .2008 .0137$

Schweigel, M., J. Vormann, and H. Martens. 2000. Mechanisms of $\mathrm{Mg}^{2+}$ transport in cultured ruminal epithelial cells. Am. J. Physiol. Gastrointest. Liver Physiol. 278:G400-G408.

Sehested, J., J. B. Andersen, O. Aaes, N. B. Kristensen, L. Diernæs, P. D. Møller, and E. Skadhauge. 2000. Feed-induced changes in the transport of butyrate, sodium and chloride ions across the isolated bovine rumen epithelium. Acta Agric. Scand. A Anim. Sci. 50:47-55. https://doi.org/10.1080/090647000423924.

Selvaraj, N. G., E. Omi, G. Gibori, and M. C. Rao. 2000. Janus kinase 2 (JAK2) regulates prolactin-mediated chloride transport in mouse mammary epithelial cells through tyrosine phosphorylation of $\mathrm{Na}^{+}-\mathrm{K}^{+}-2 \mathrm{Cl}^{-}$cotransporter. Mol. Endocrinol. 14:2054-2065. https://doi.org/10.1210/mend.14.12.0568.

Shennan, D. B., and M. Peaker. 2000. Transport of milk constituents by the mammary gland. Physiol. Rev. 80:925-951.

Shire, J., and D. Beede. 2013. Influence of DCAD on lactational performance: A review of some practical considerations. Pages 91-98 in Proc. 2013 Penn State Dairy Cattle Nutr. Workshop, Grantville, PA. Penn State Extension, University Park.

Vlaeminck, B., C. Dufour, A. M. van Vuuren, A. R. J. Cabrita, R. J. Dewhurst, D. Demeyer, and V. Fievez. 2005. Use of odd and branched-chain fatty acids in rumen contents and milk as a potential microbial marker. J. Dairy Sci. 88:1031-1042. https://doi. org/10.3168/jds.S0022-0302(05)72771-5.

Vlaeminck, B., V. Fievez, A. Cabrita, A. Fonseca, and R. Dewhurst. 2006. Factors affecting odd-and branched-chain fatty acids in milk: A review. Anim. Feed Sci. Technol. 131:389-417. https://doi. org $/ 10.1016 / j$.anifeedsci.2006.06.017.

West, J. W., C. E. Coppock, D. H. Nave, and G. T. Schelling. 1986. Effects of potassium buffers on feed intake in lactating dairy cows and on rumen fermentation in vivo and in vitro. J. Dairy Sci. 69:124-134. https://doi.org/10.3168/jds.S0022-0302(86)80376-9. 